\title{
Annex 1
}

Statutory Laws and Cases 

Annex 1

Statutory Laws and Cases 


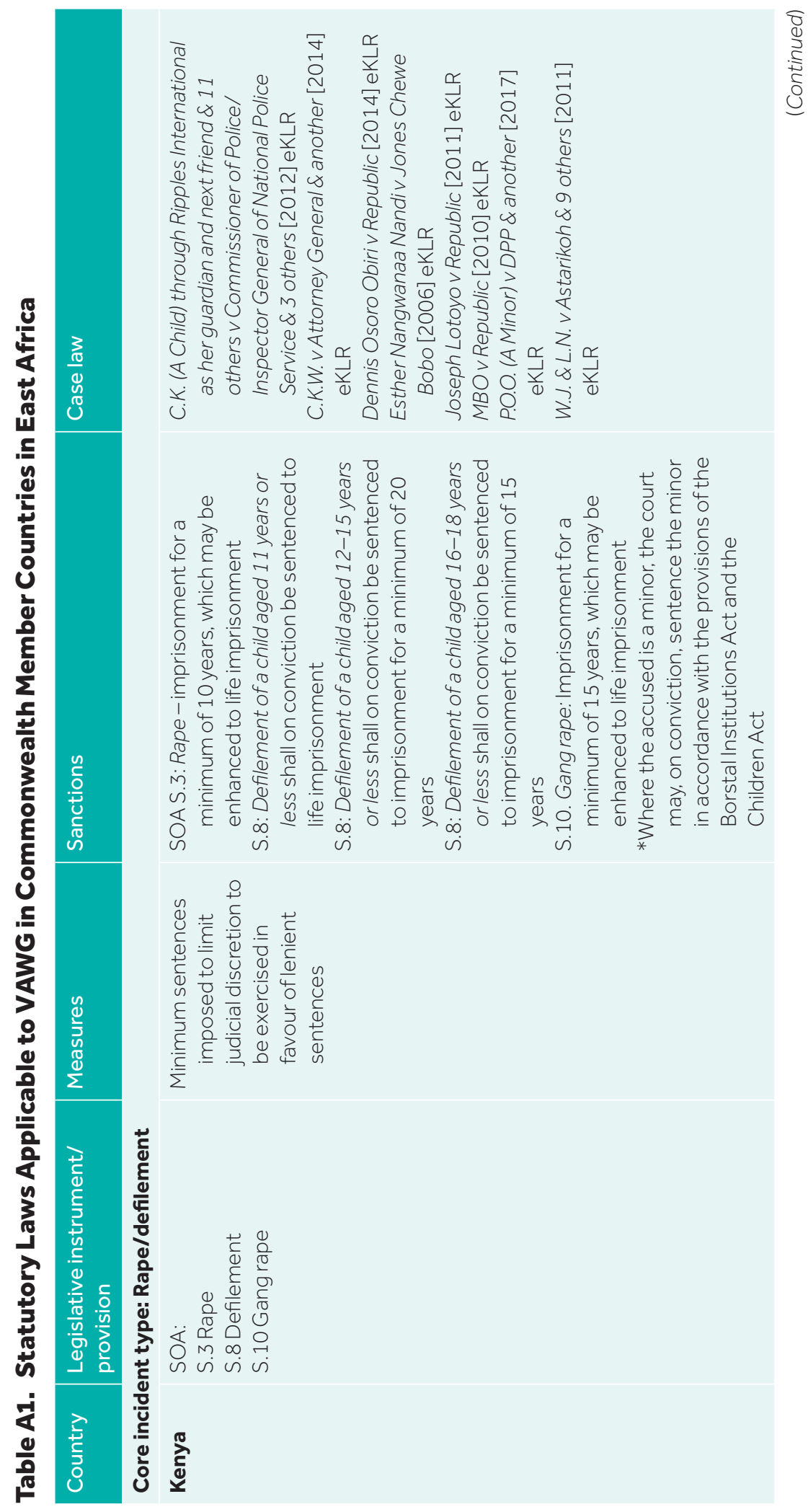




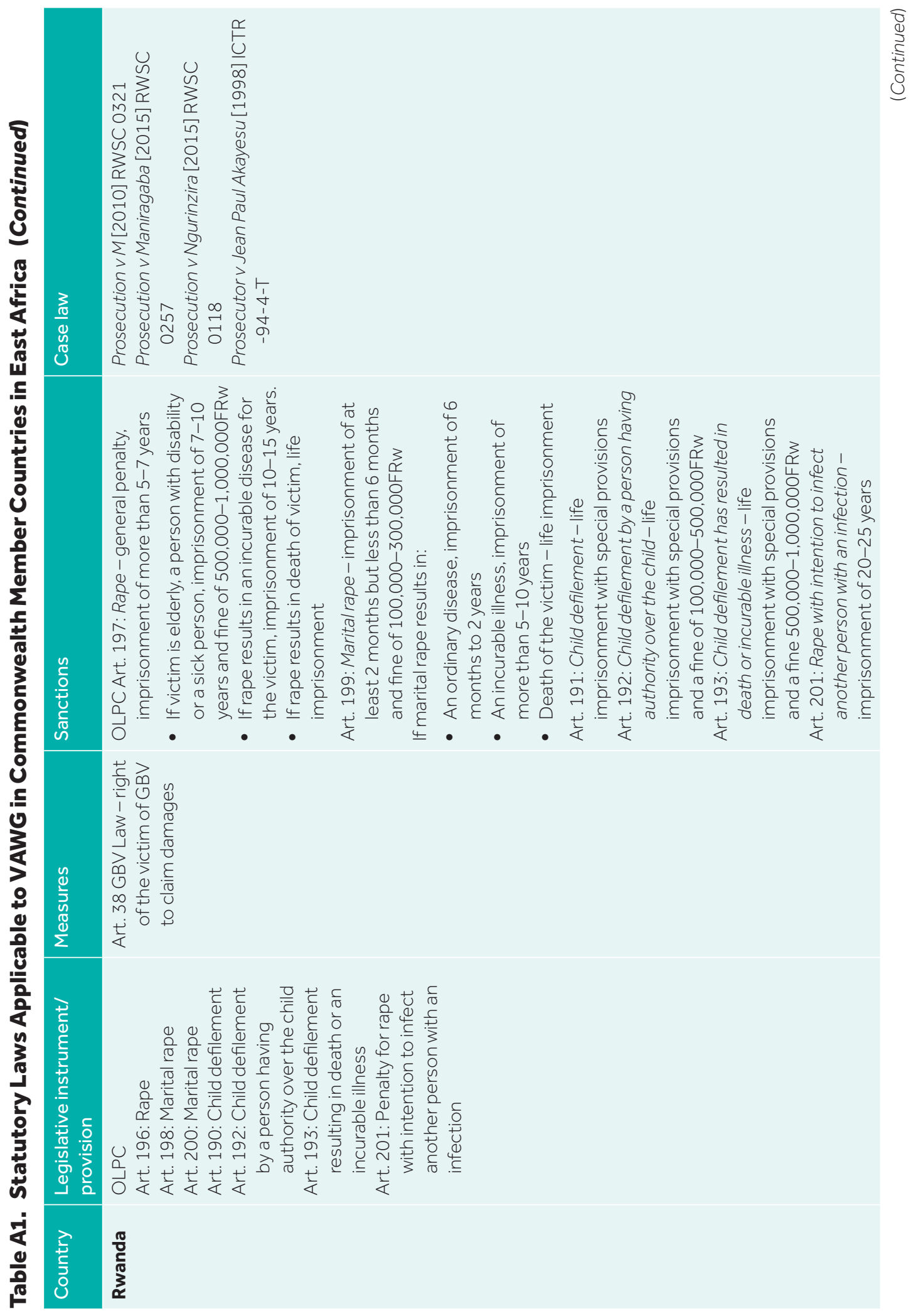




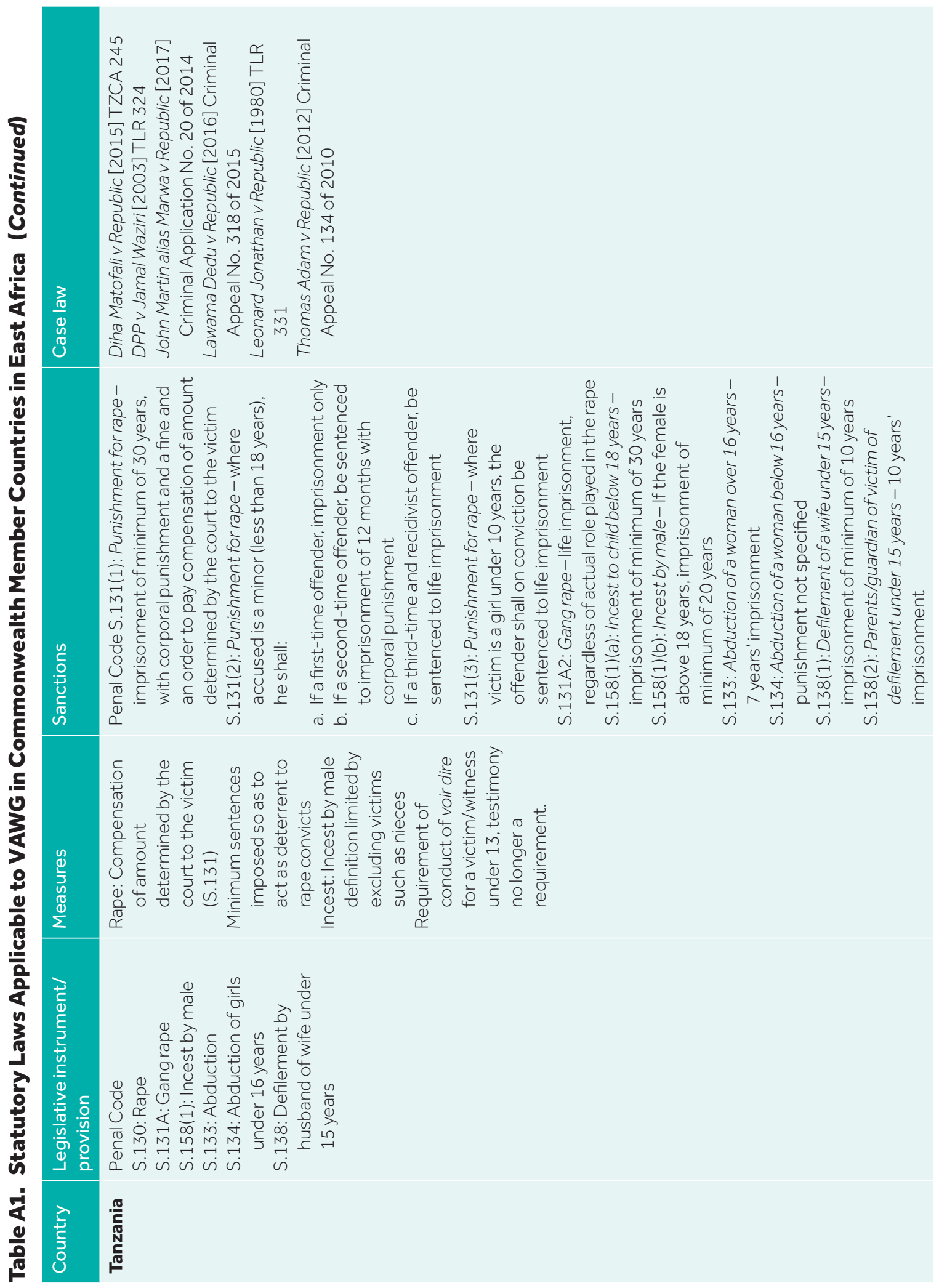




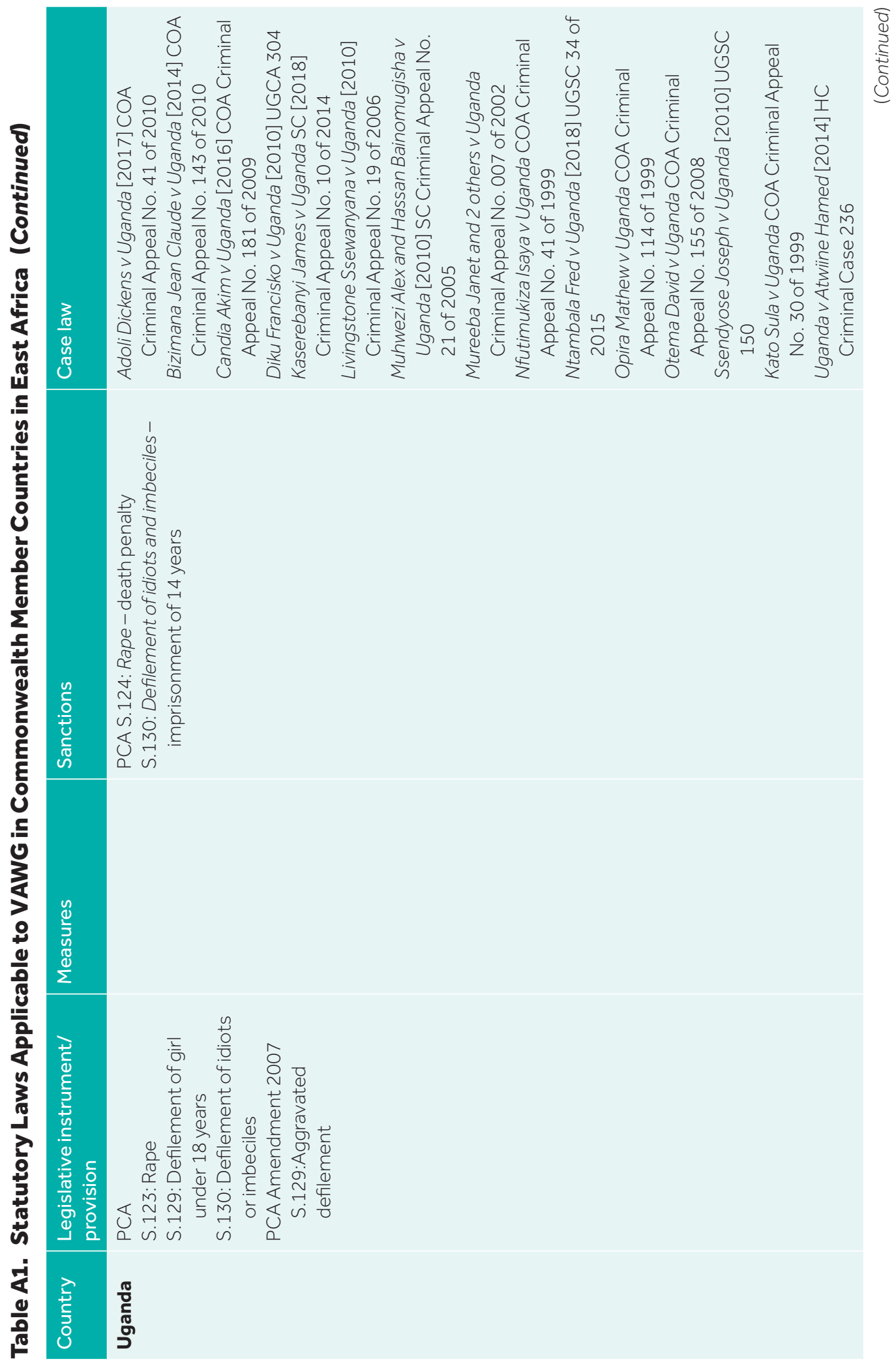




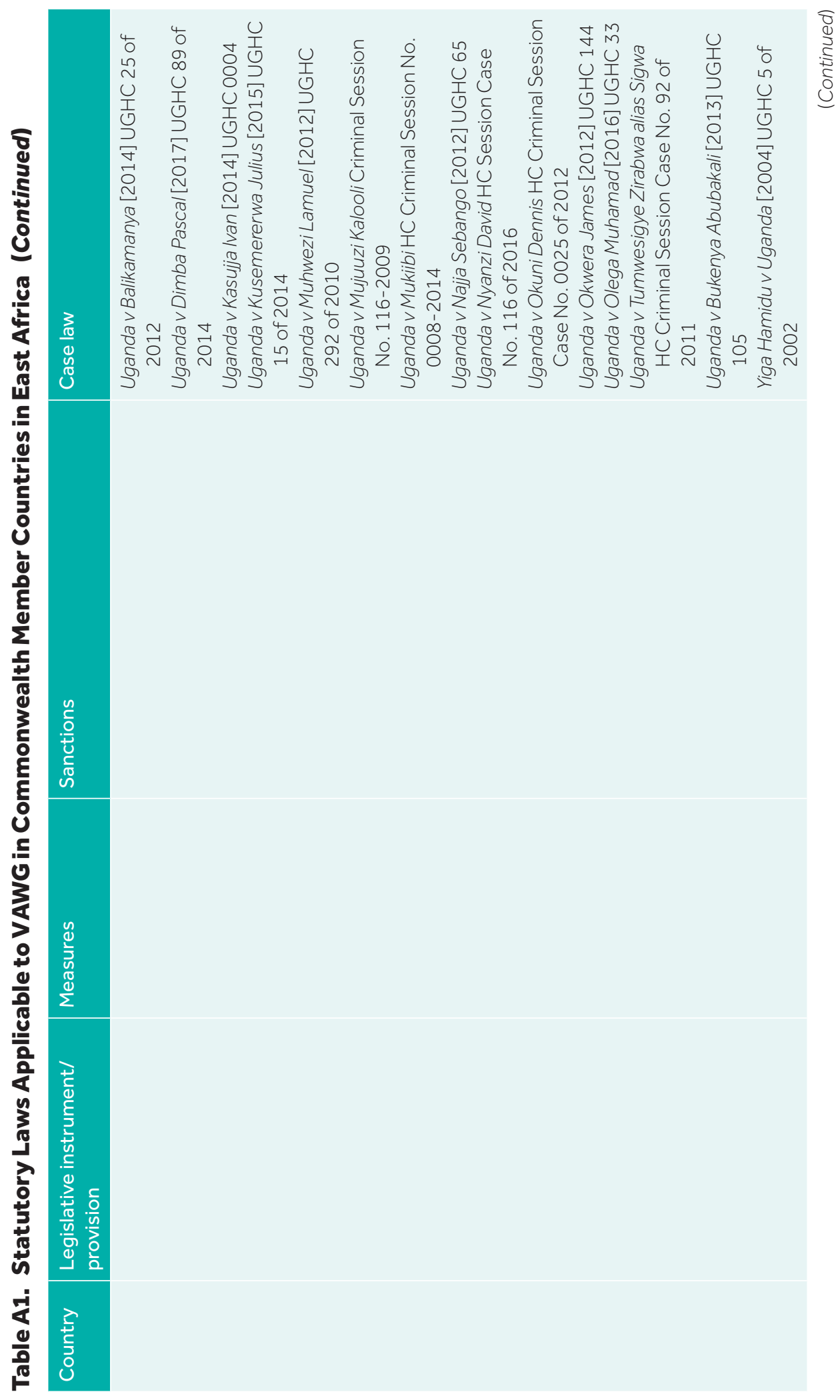




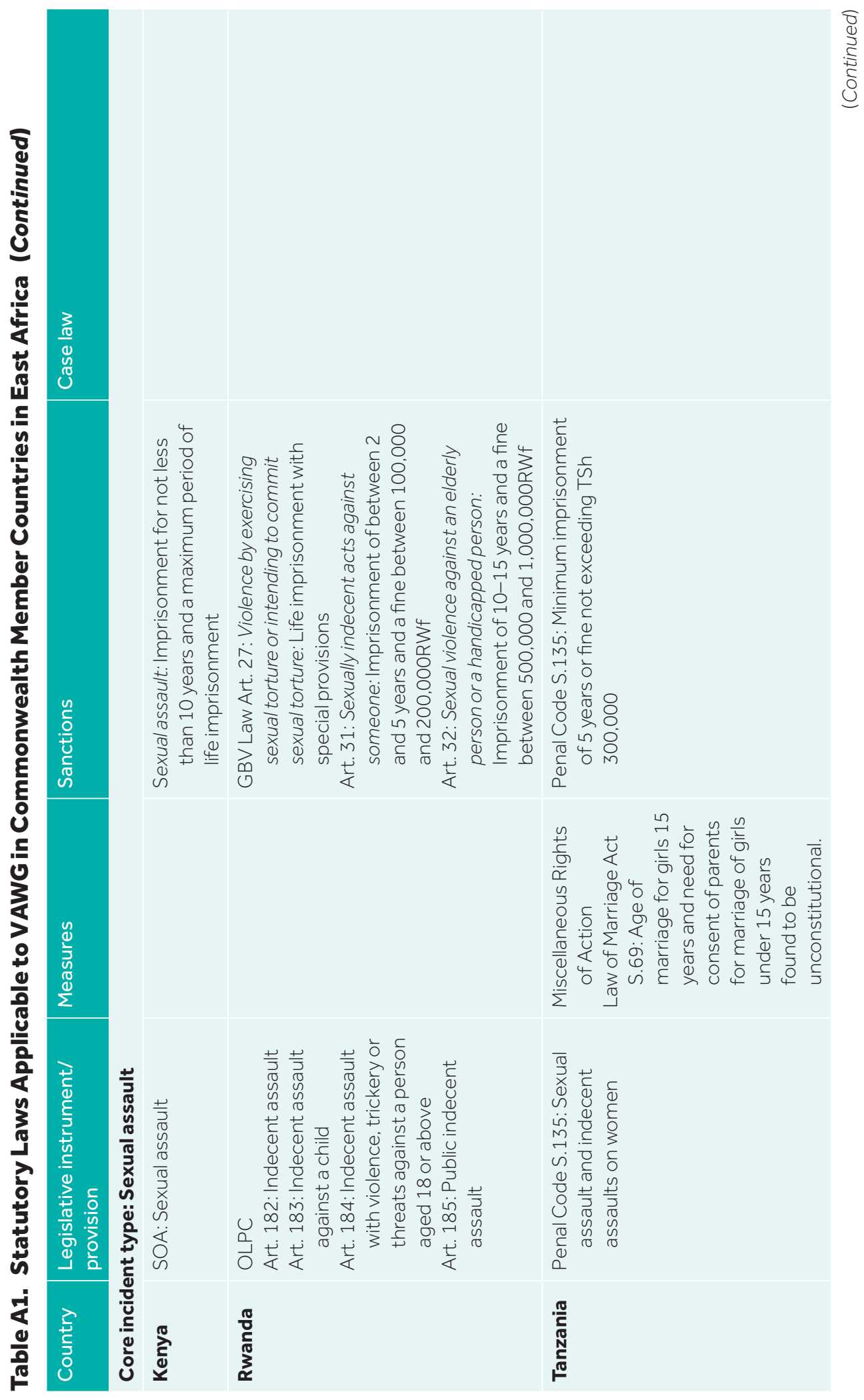




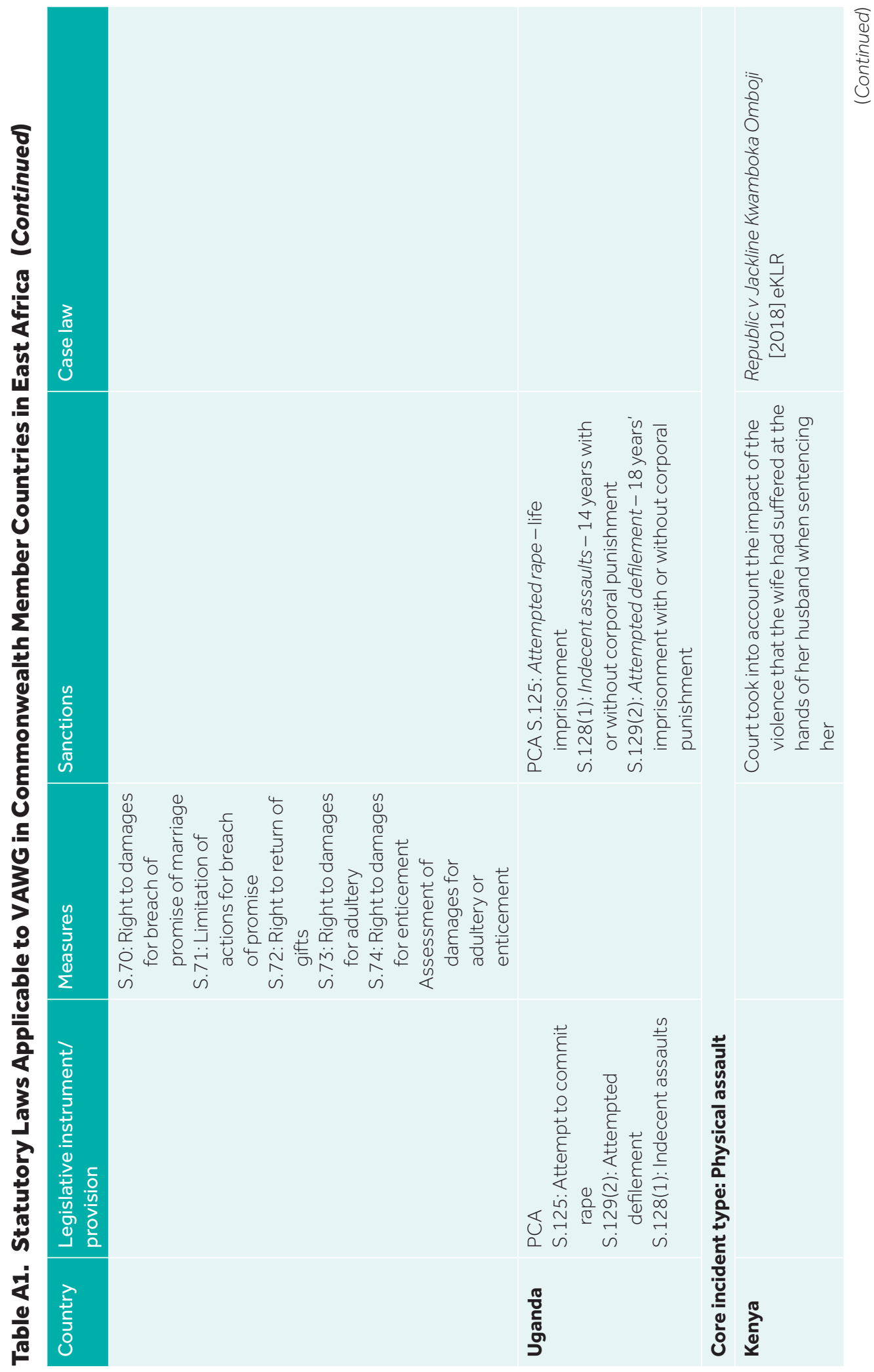




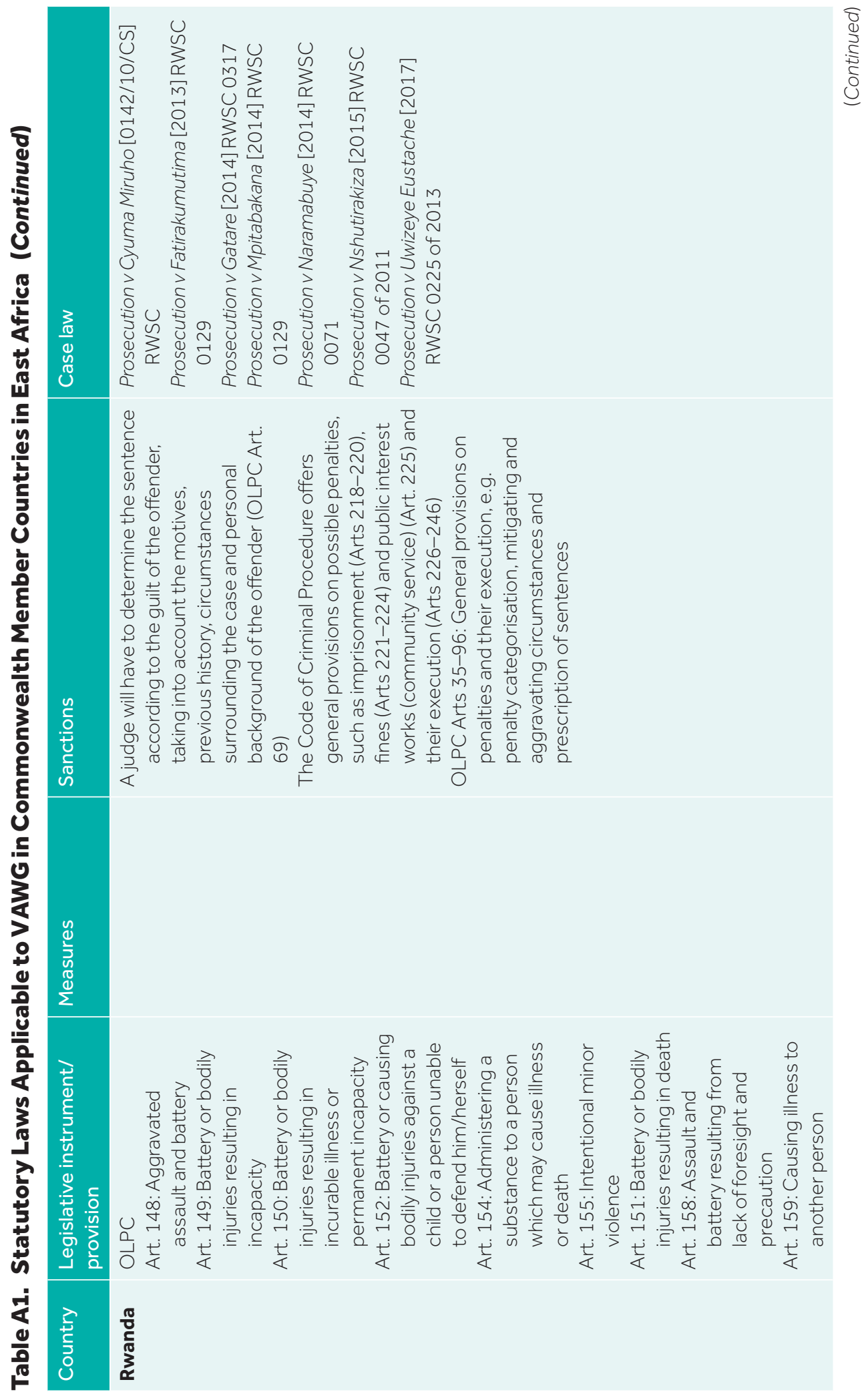




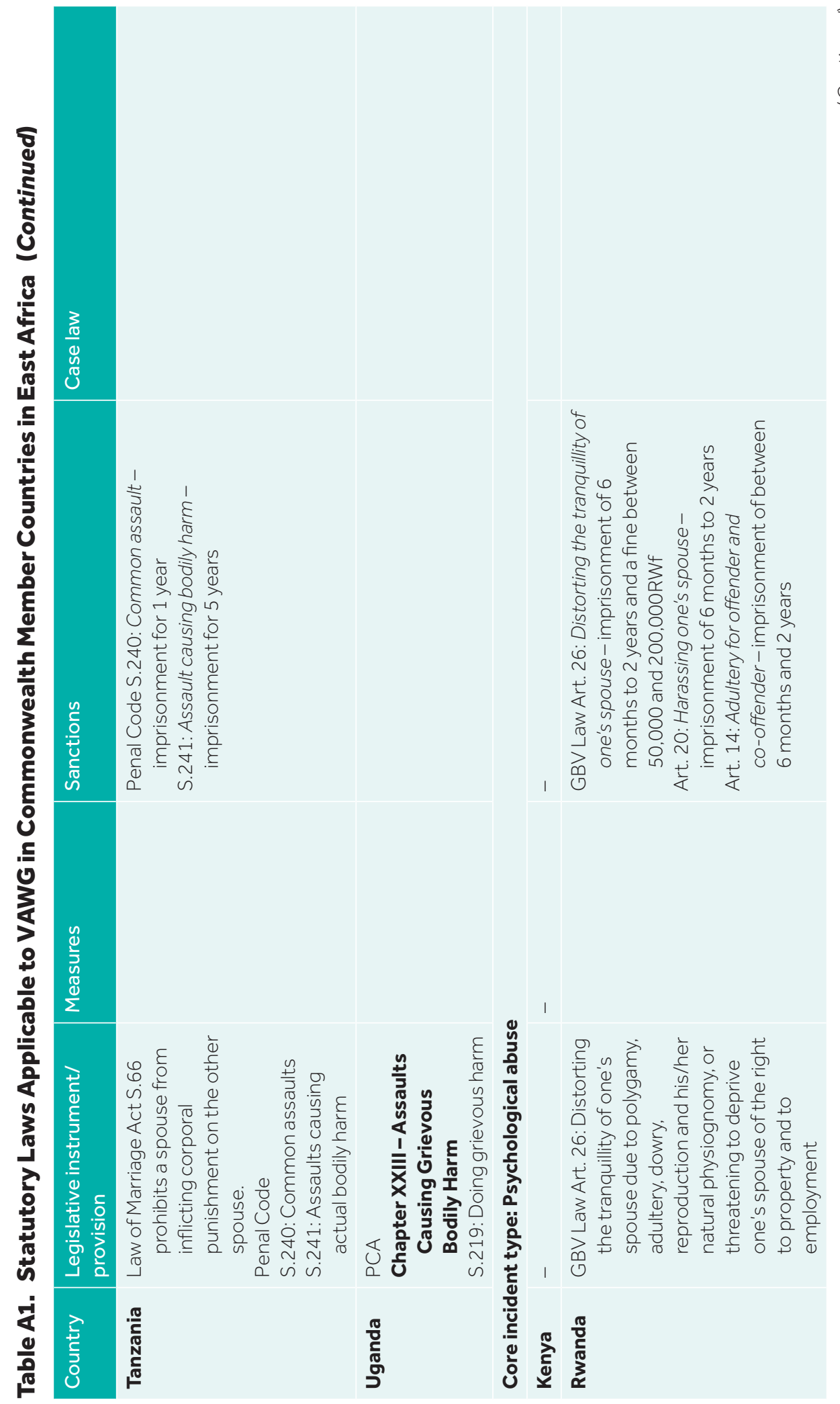




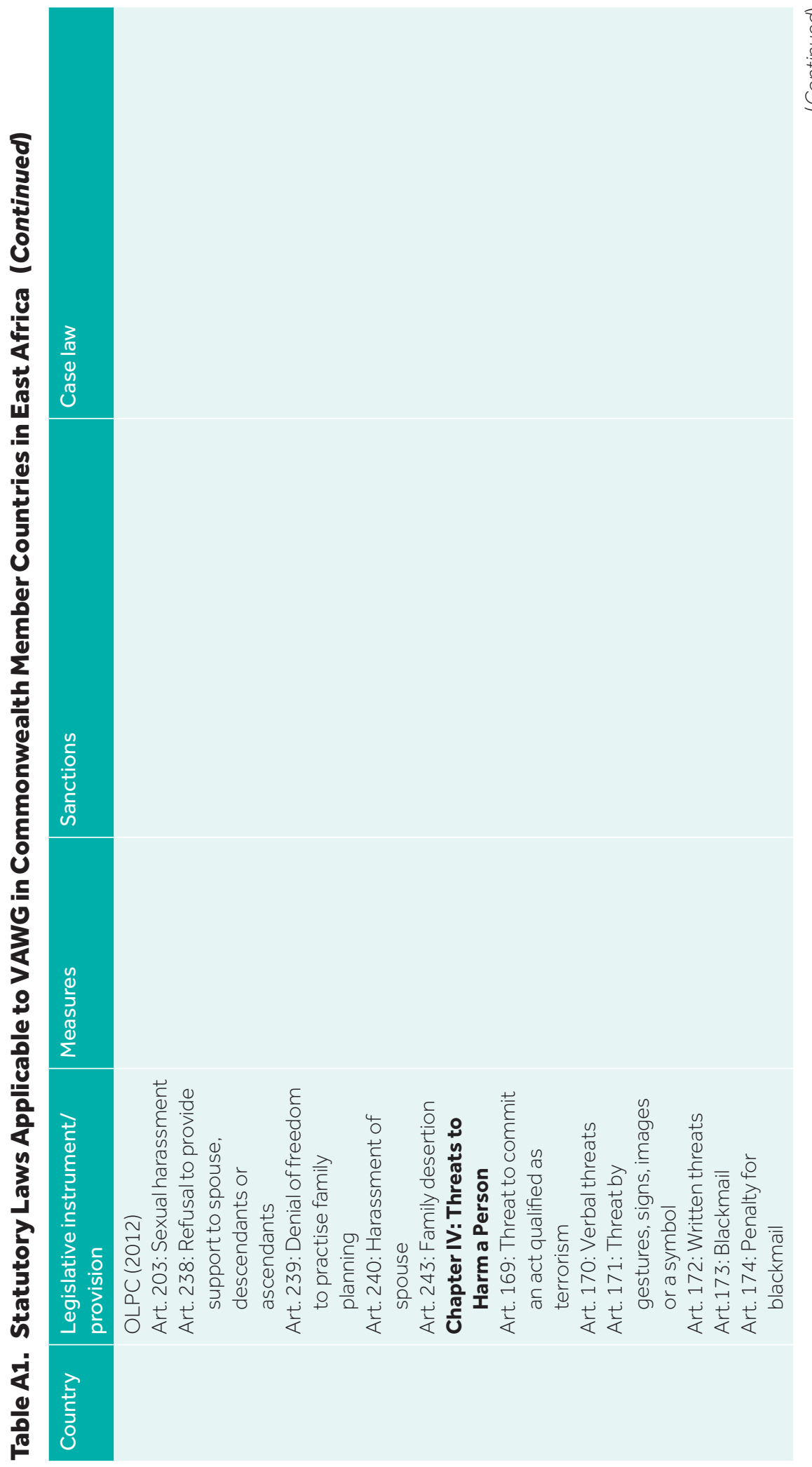




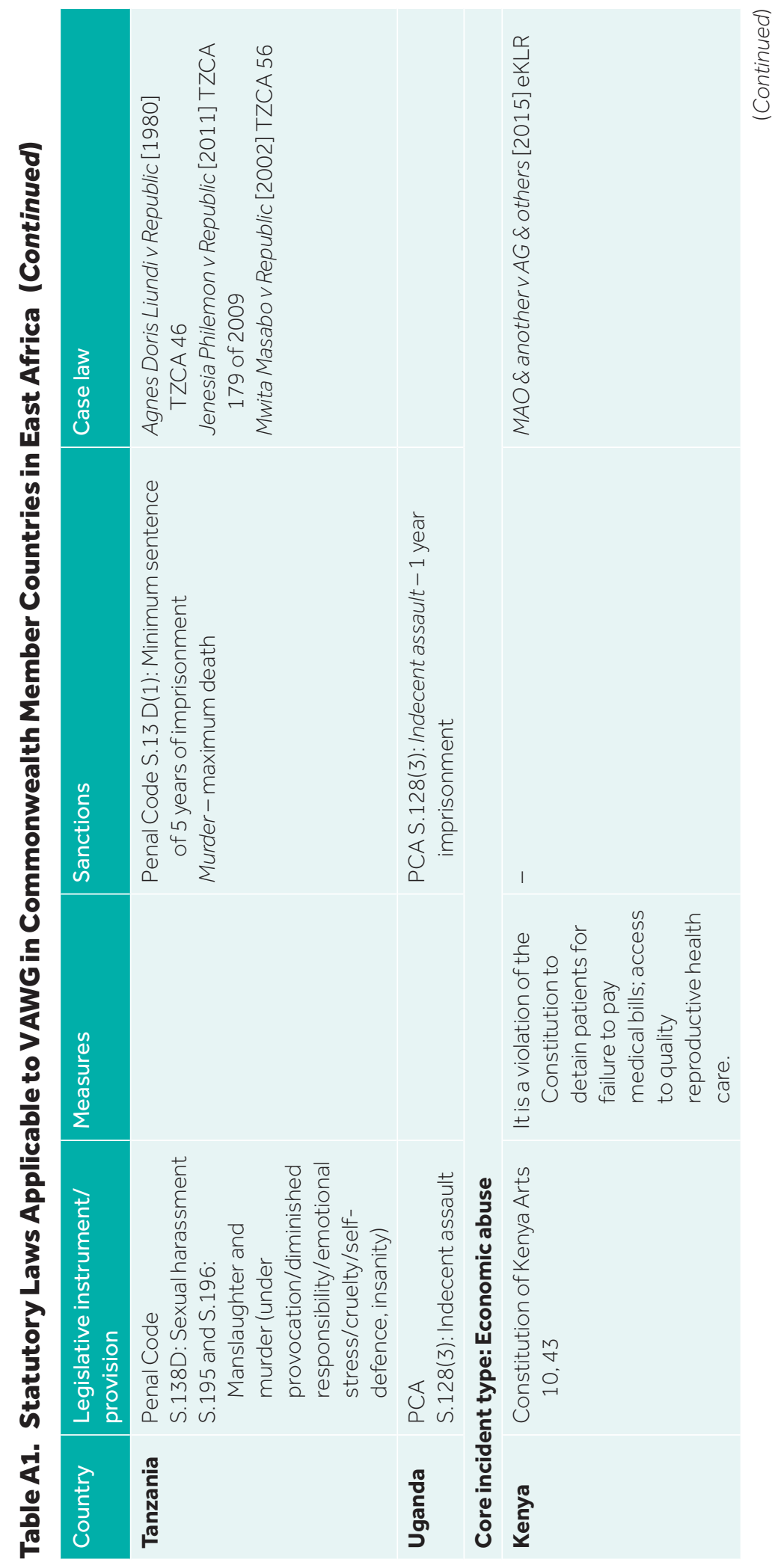




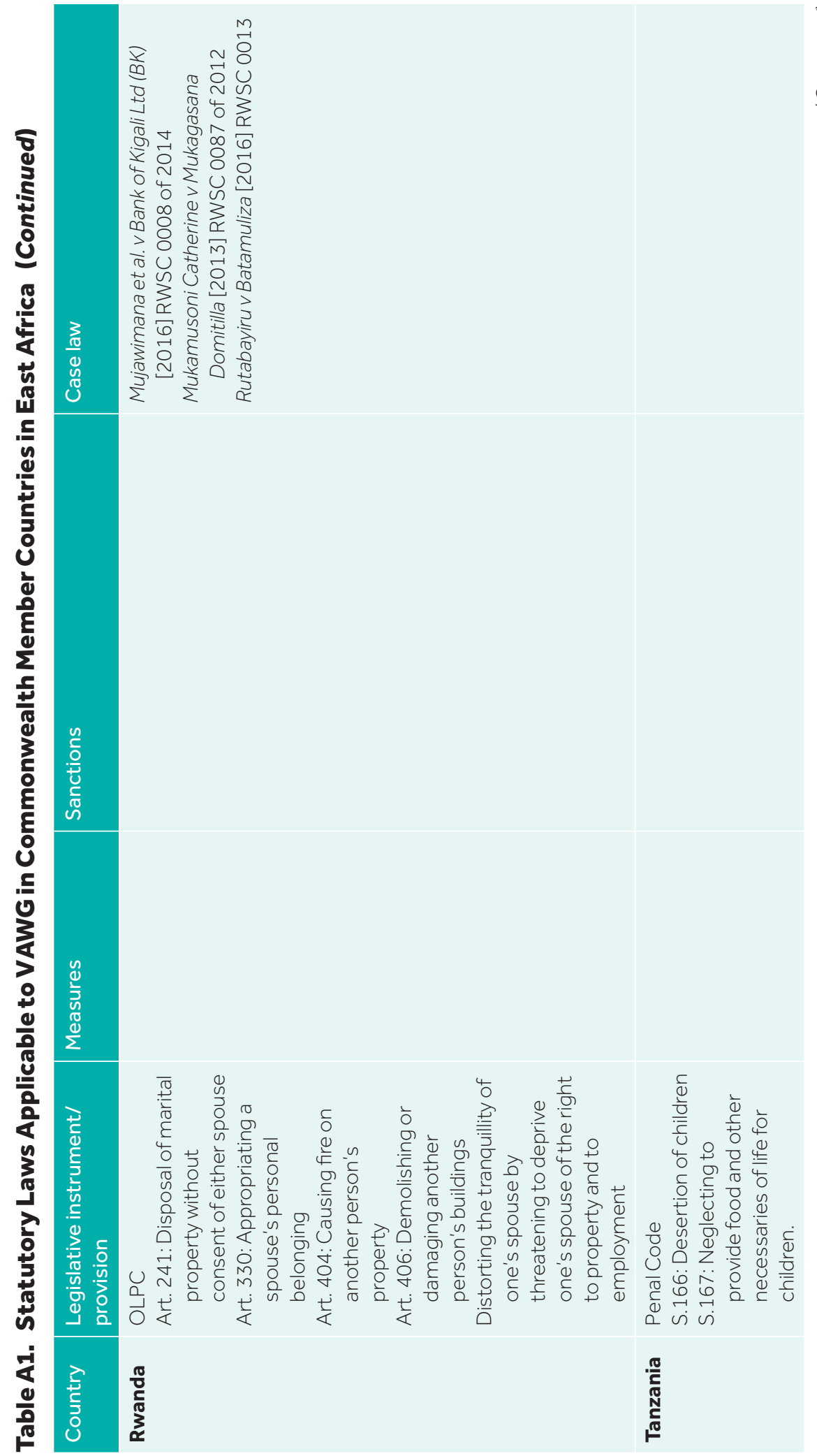




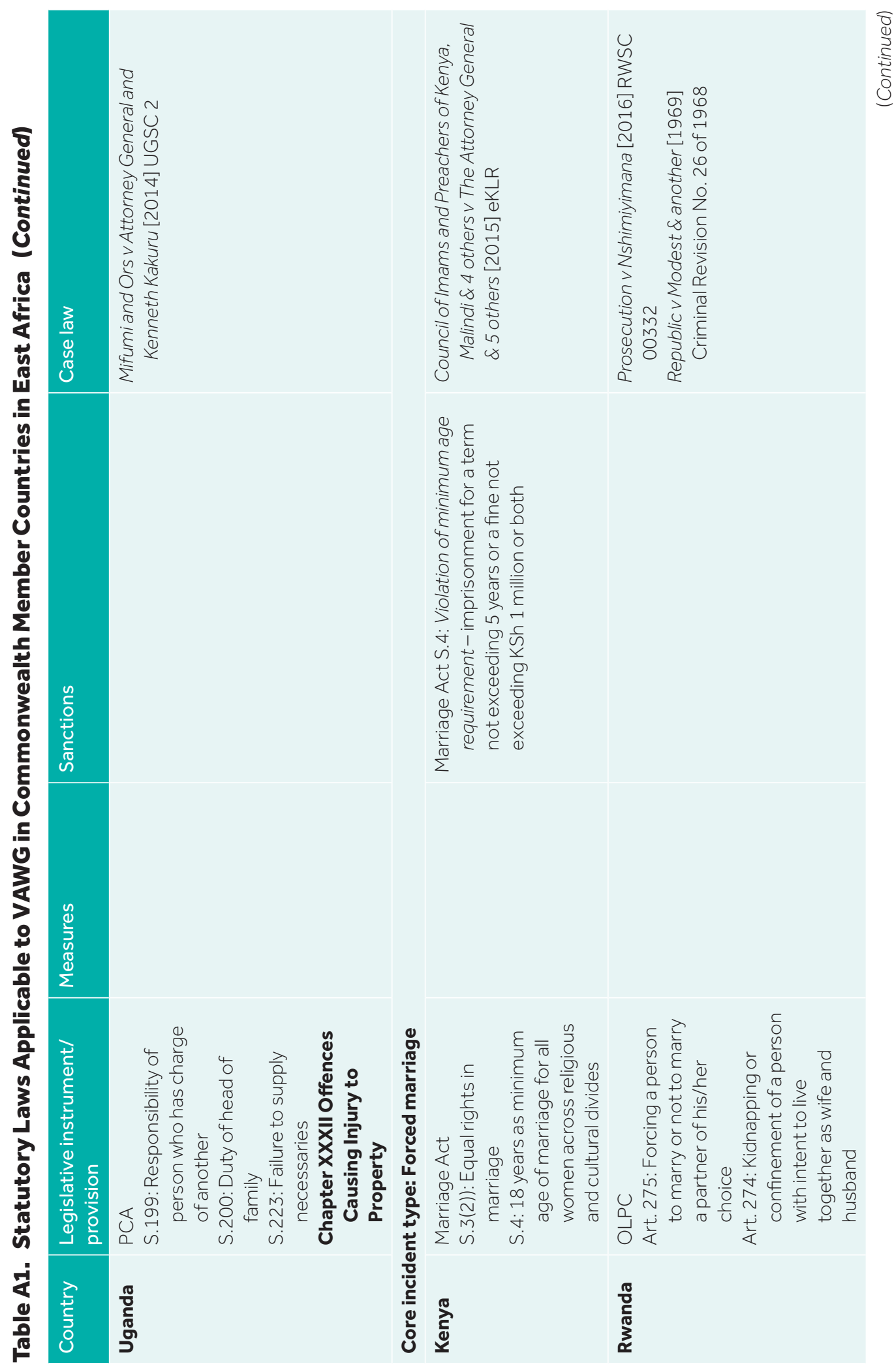




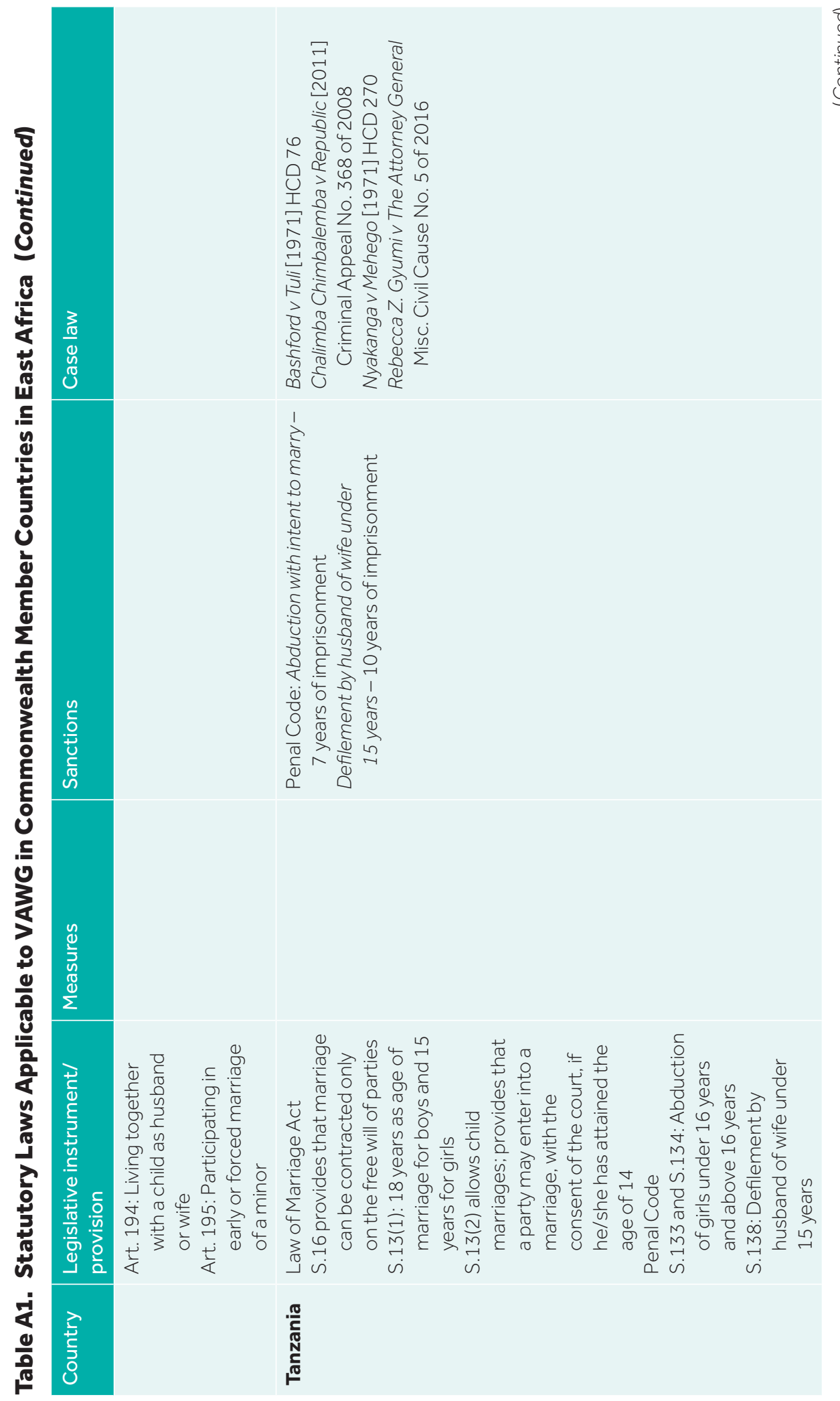




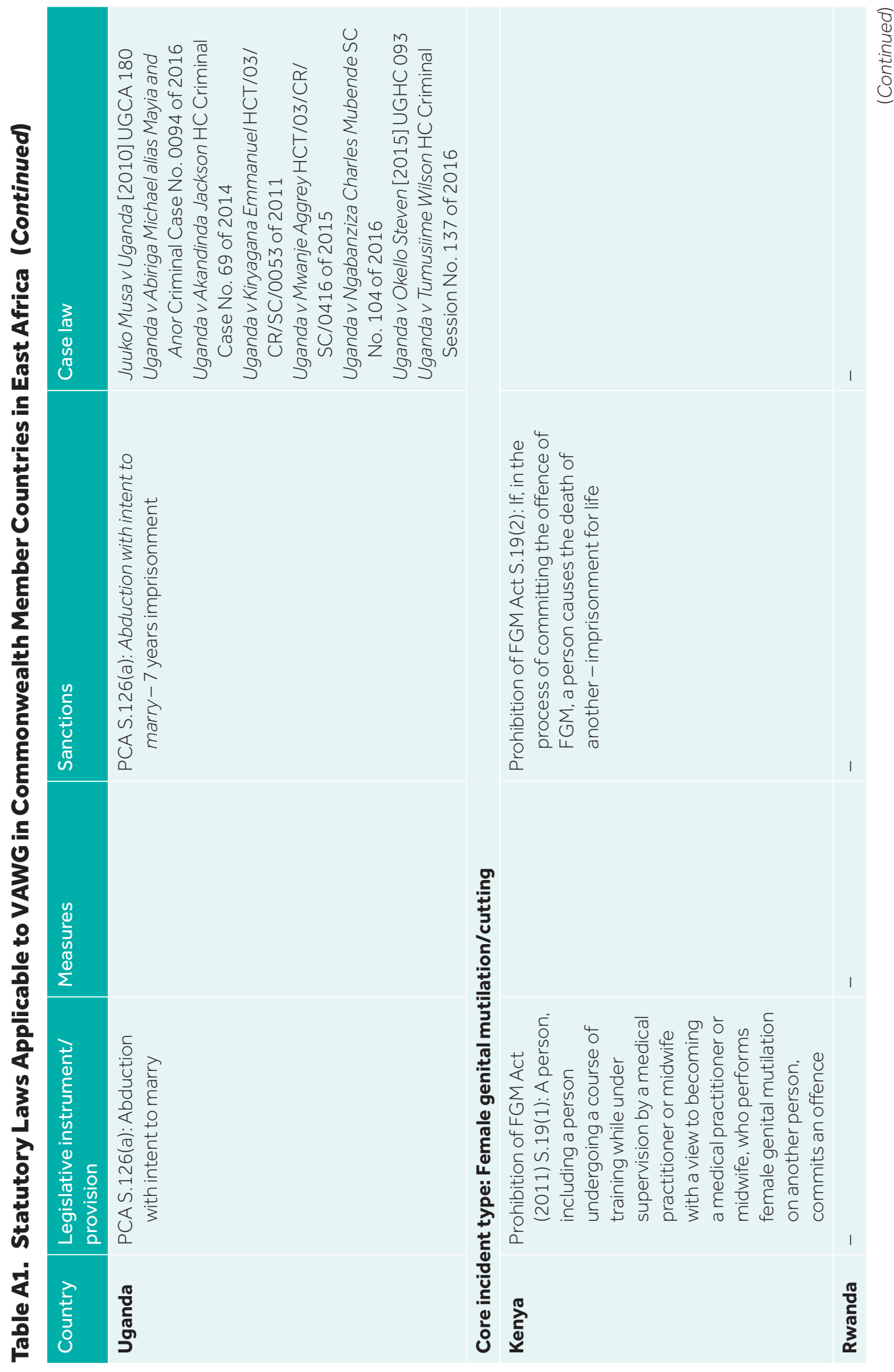









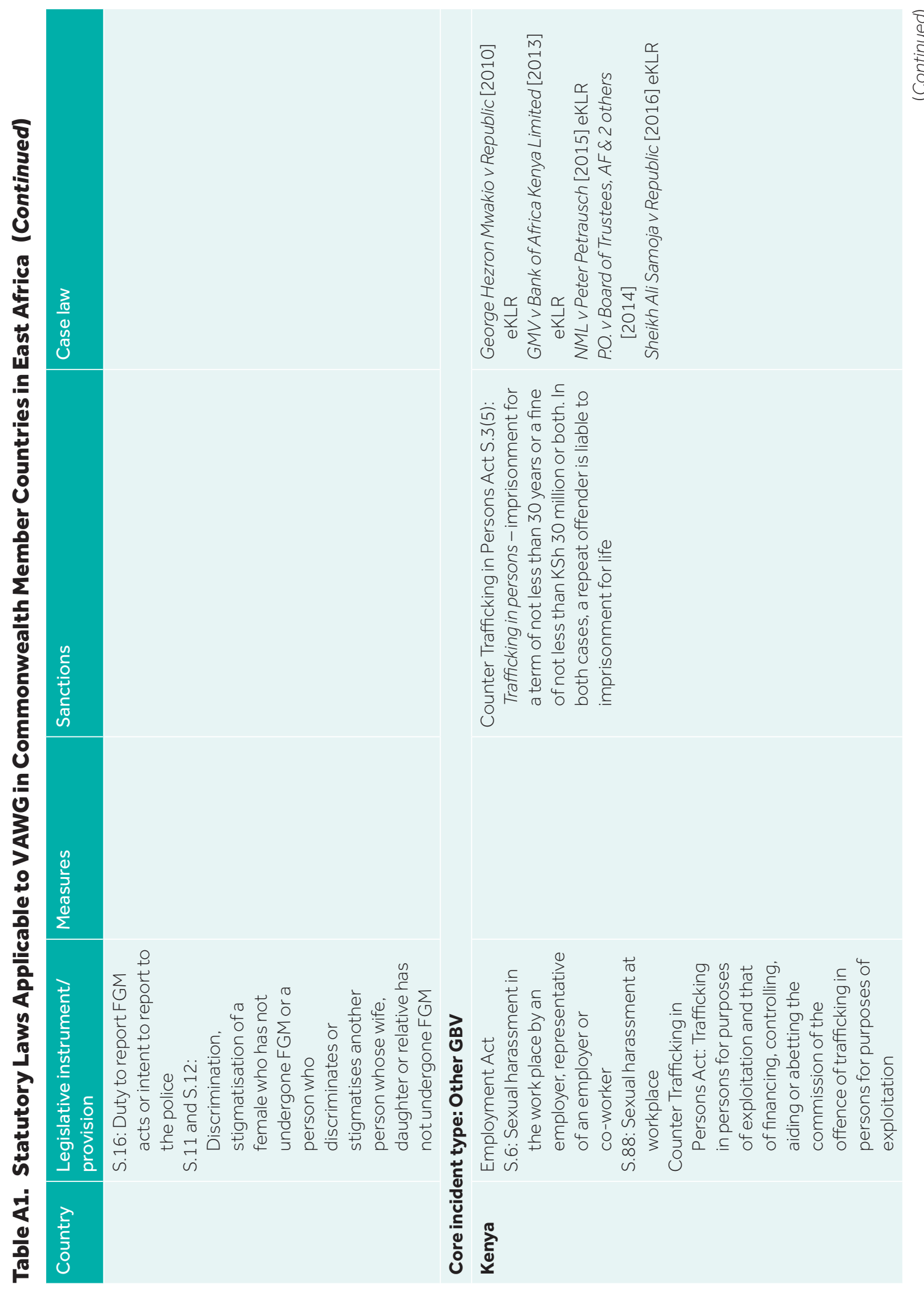




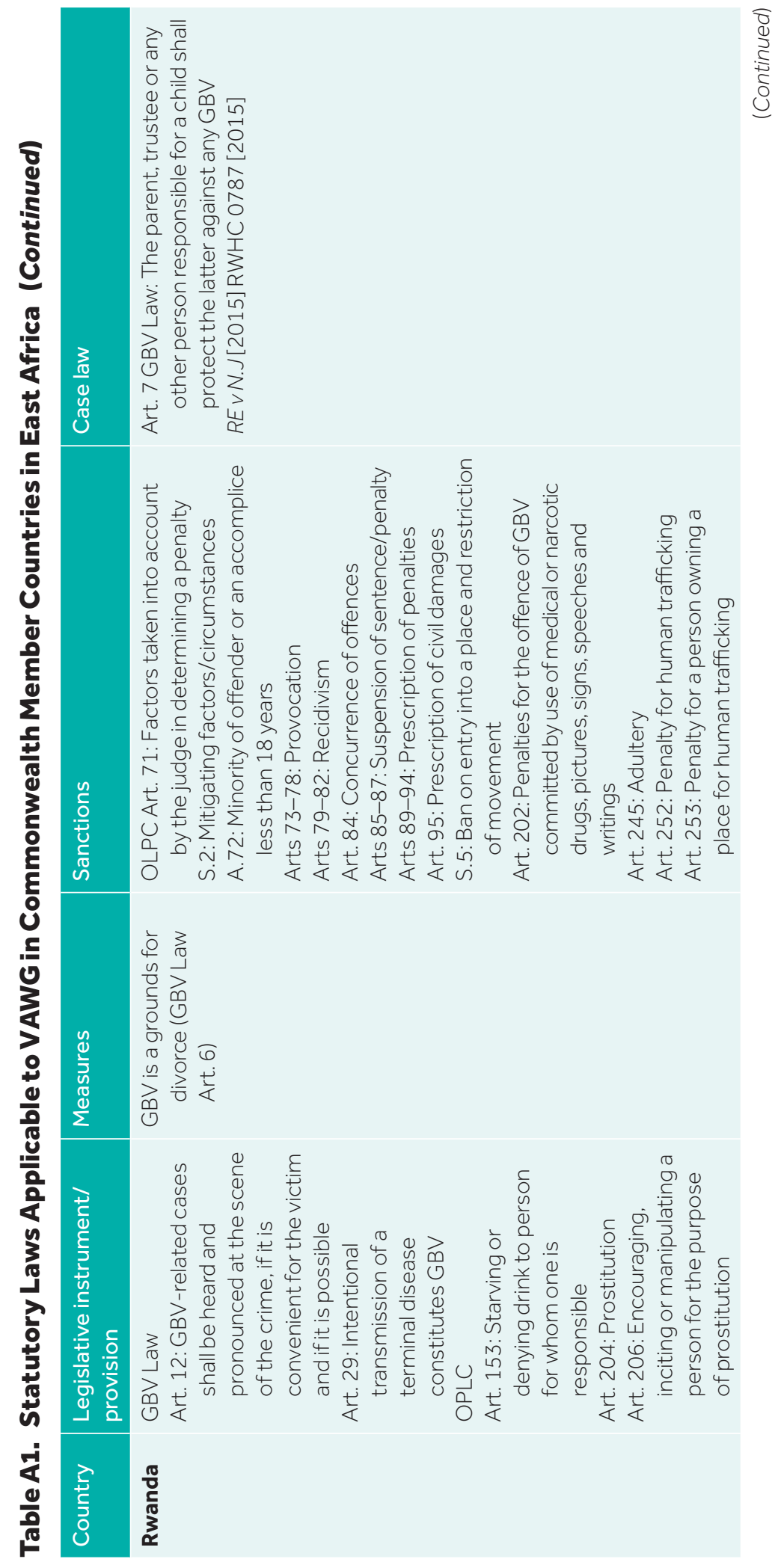




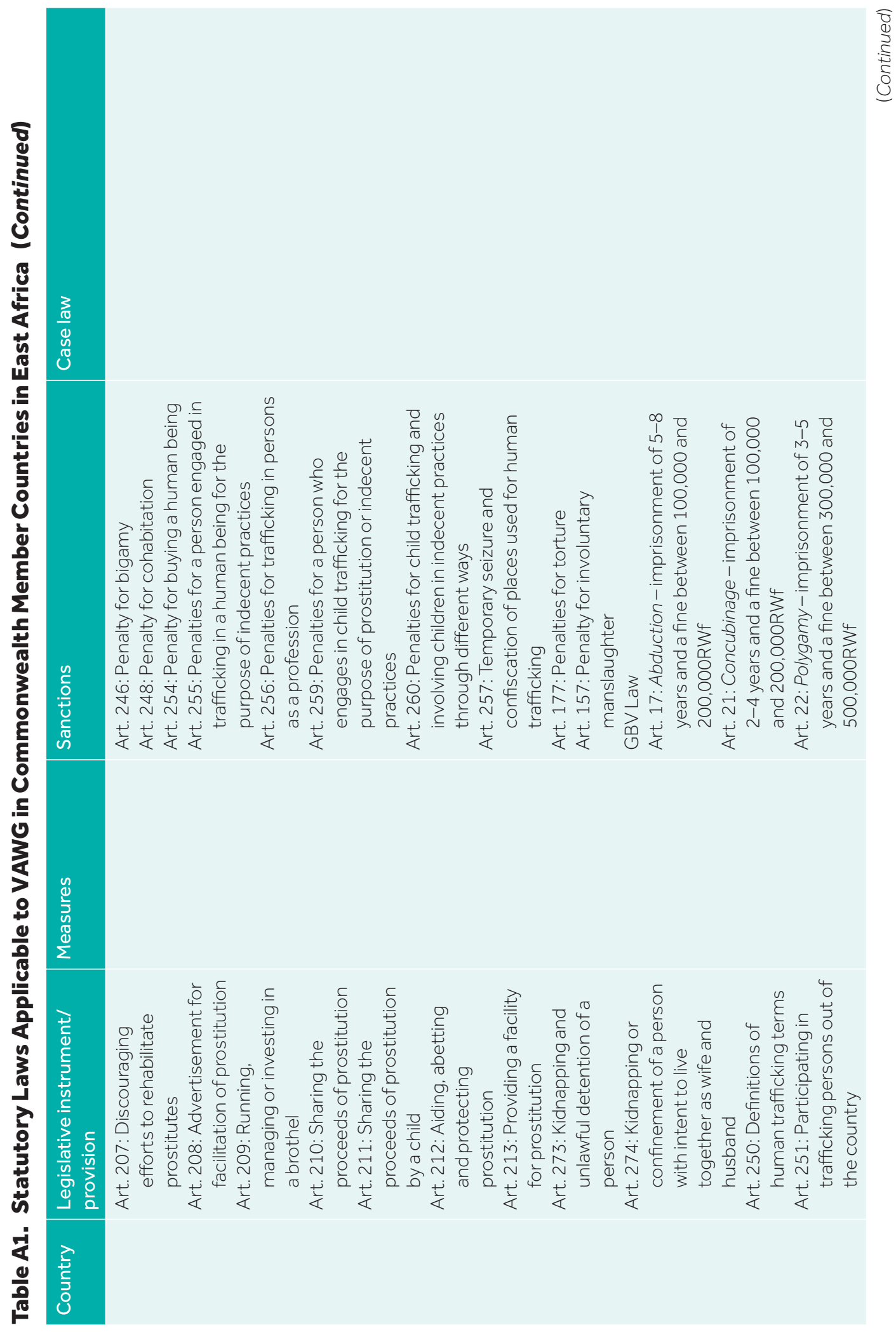




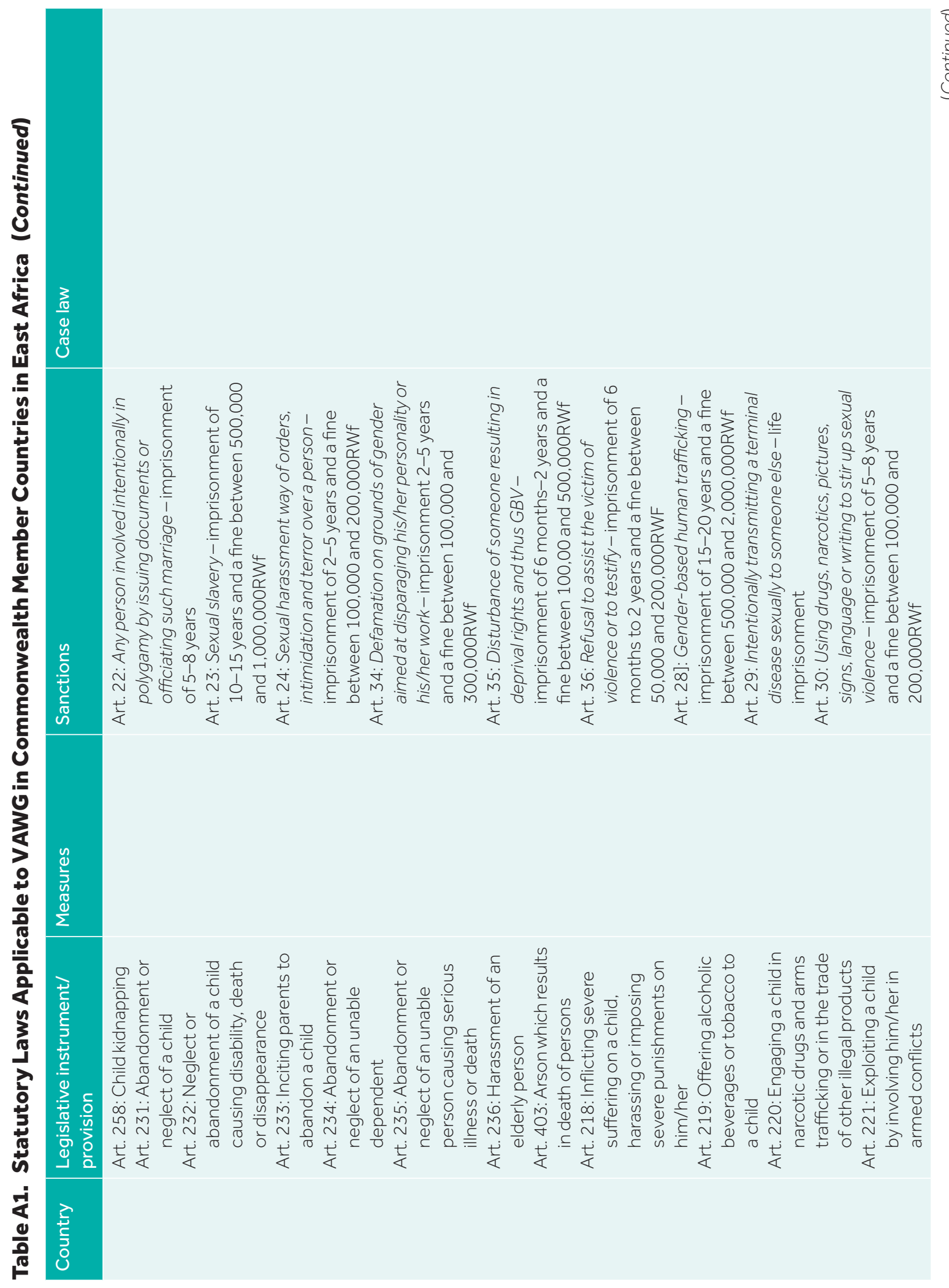




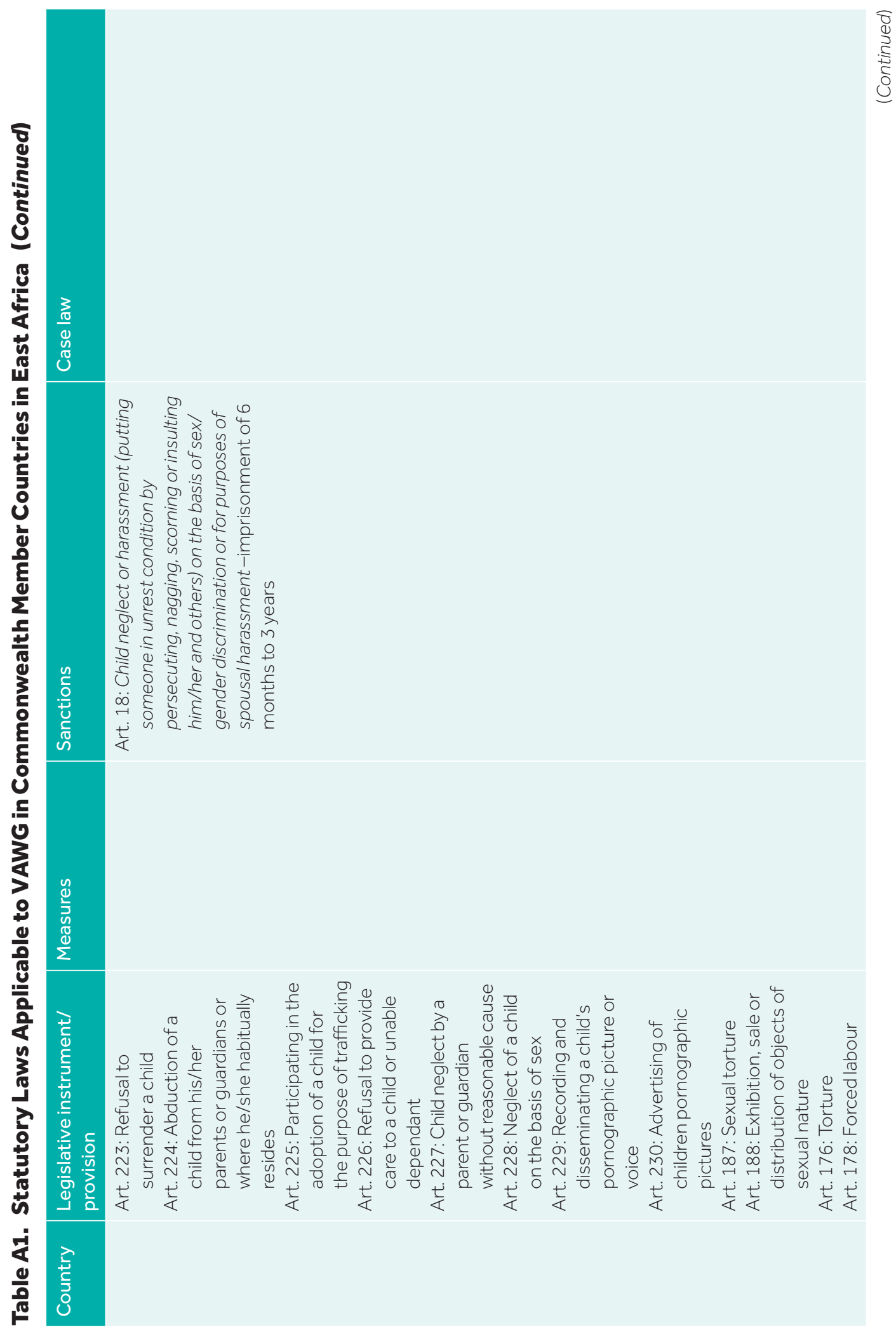



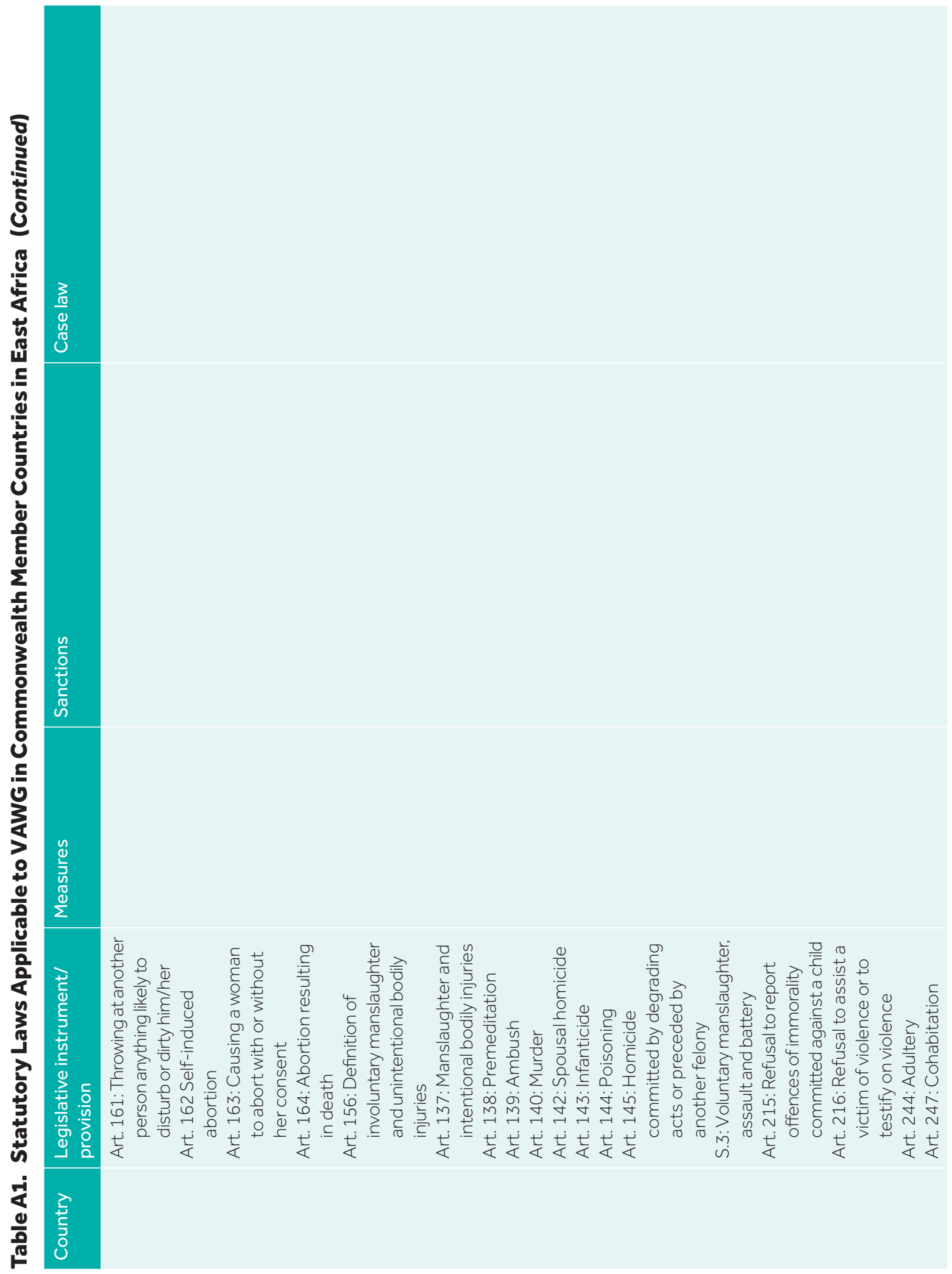


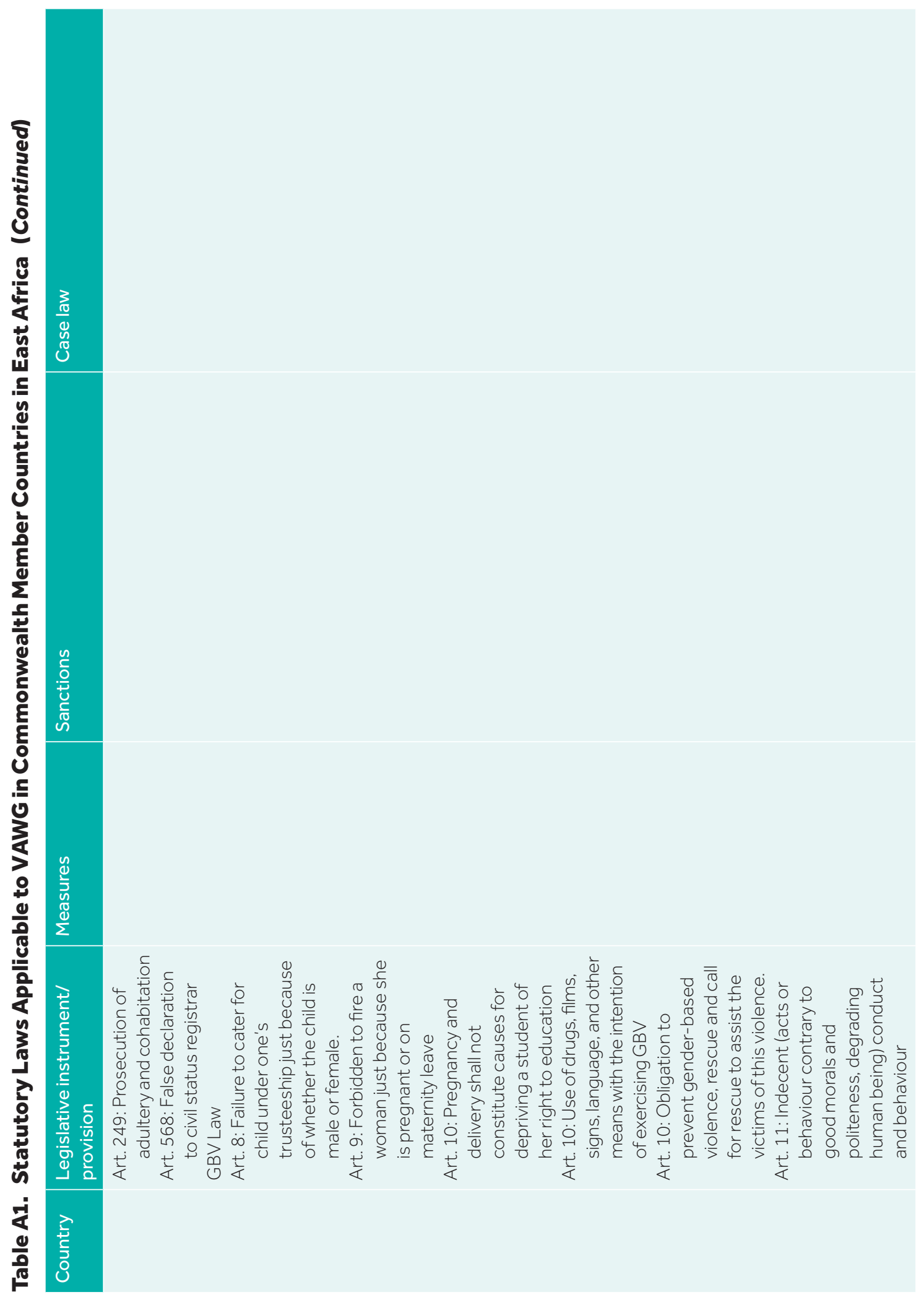




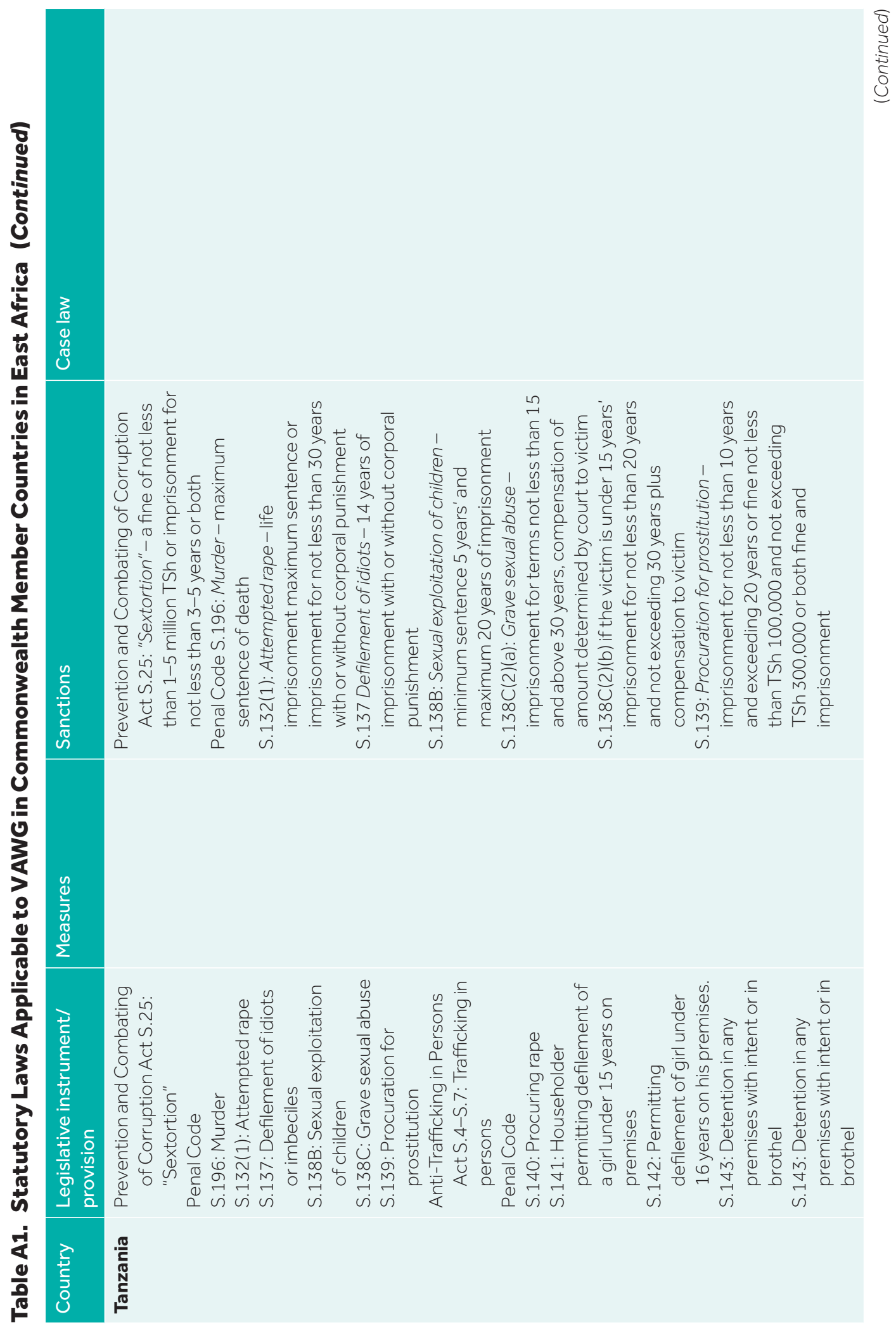




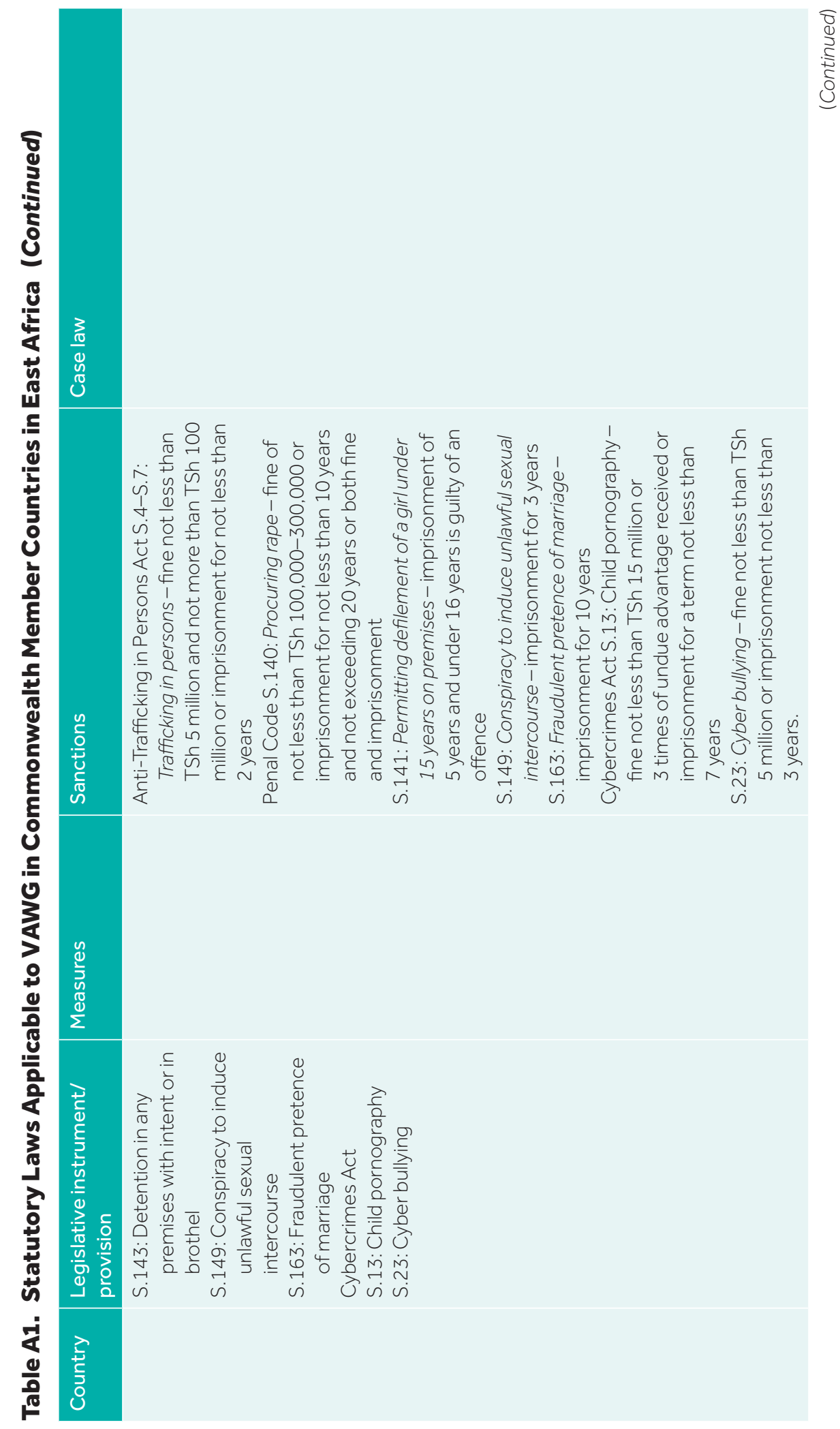




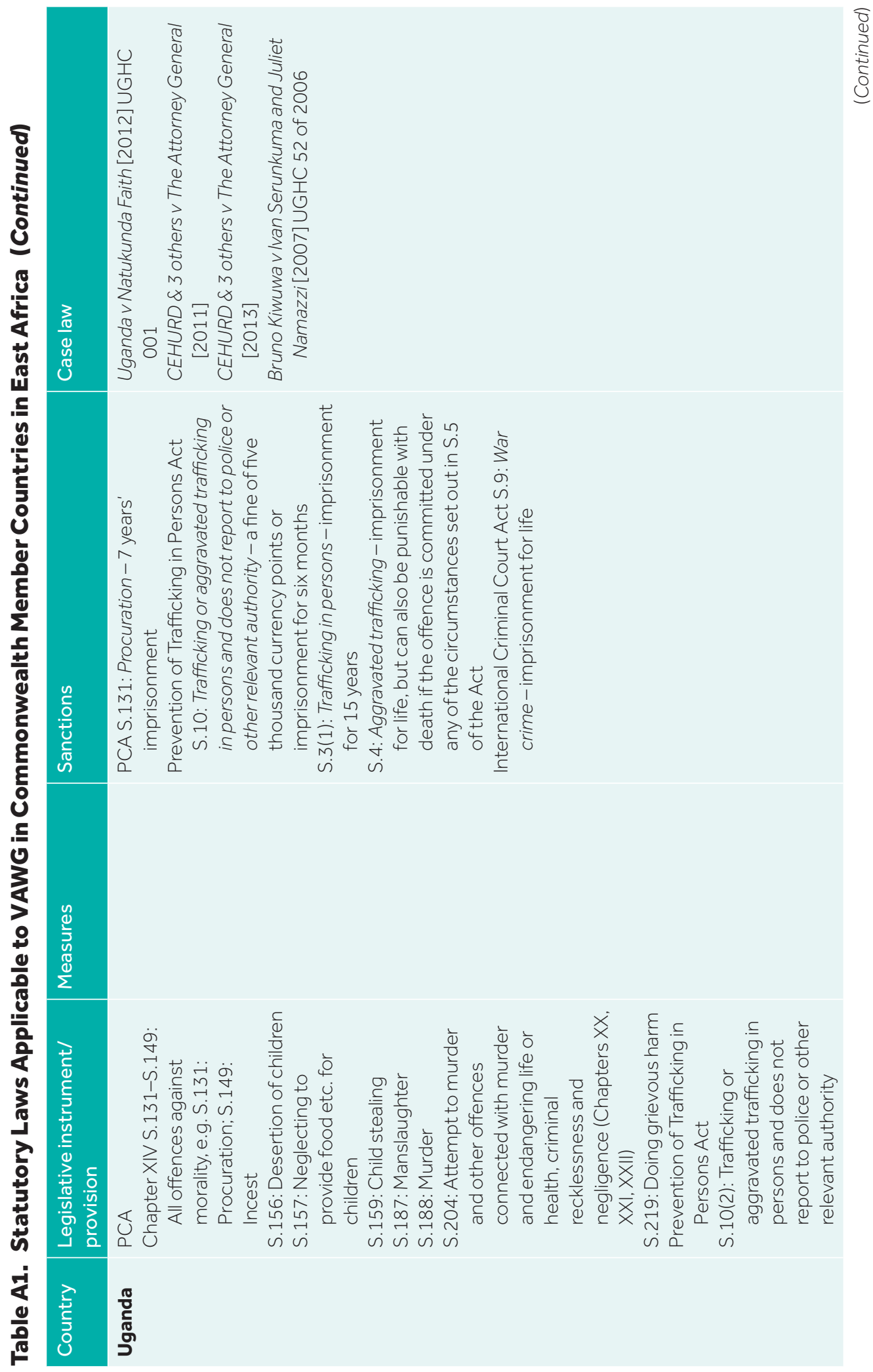




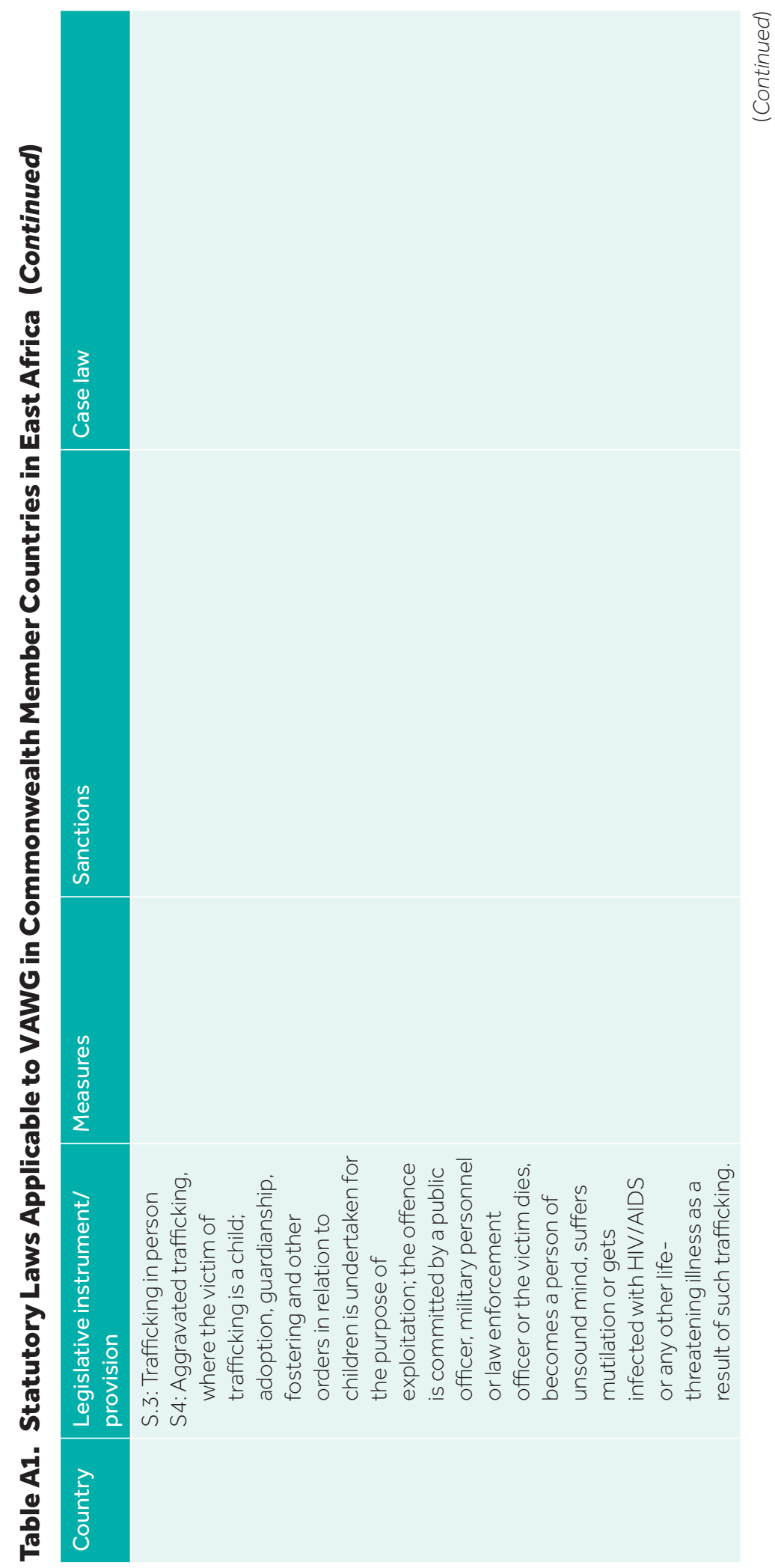




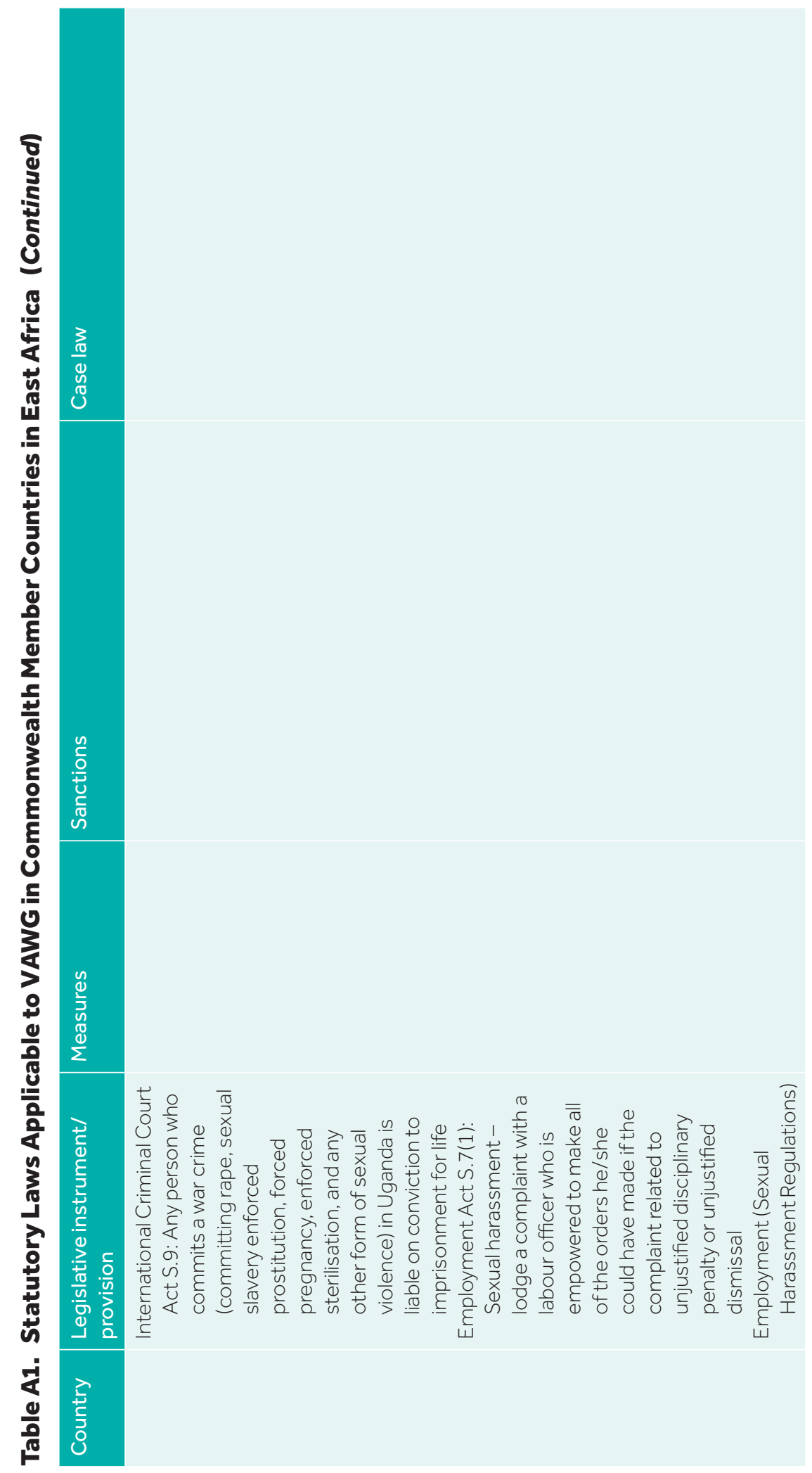




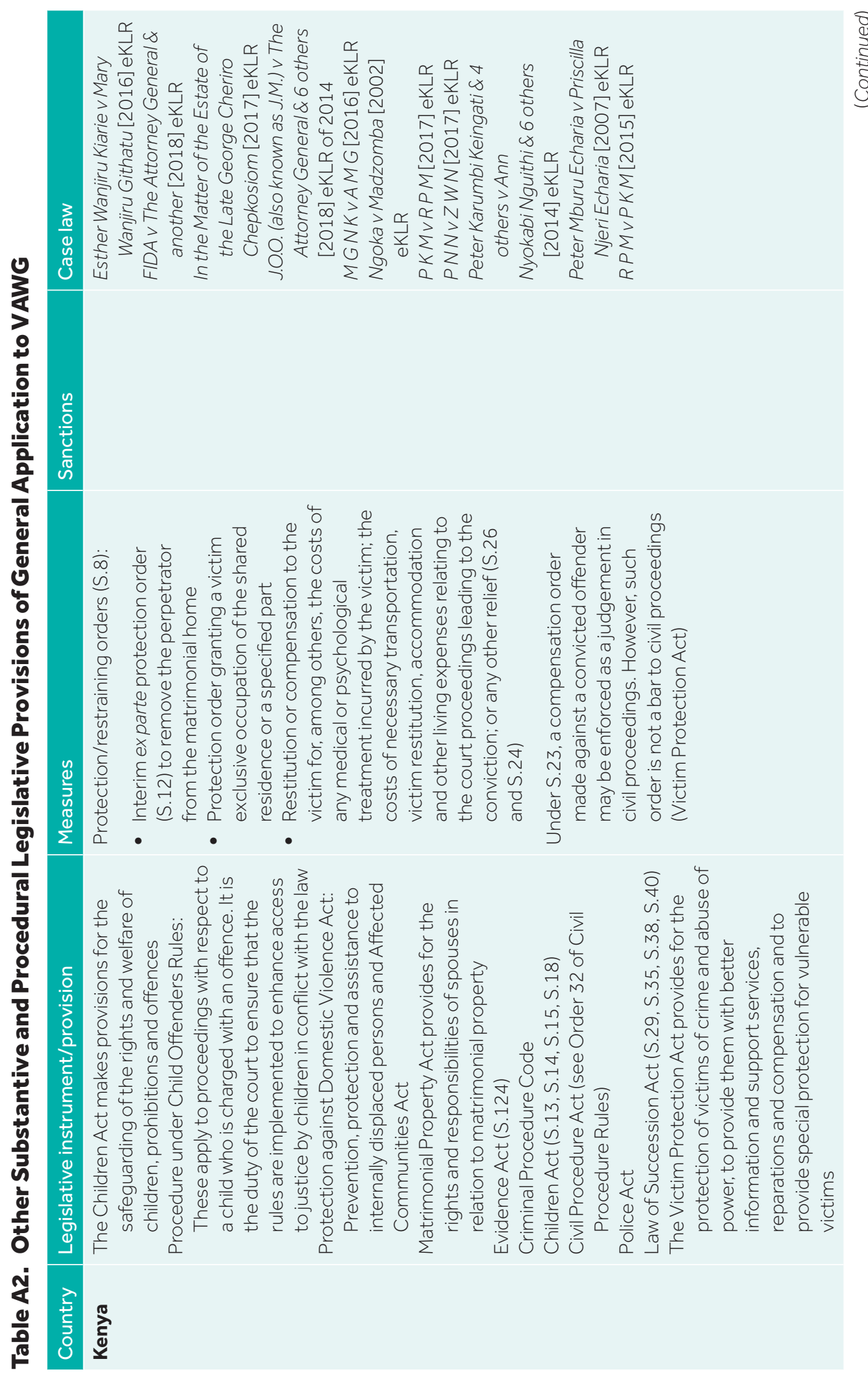




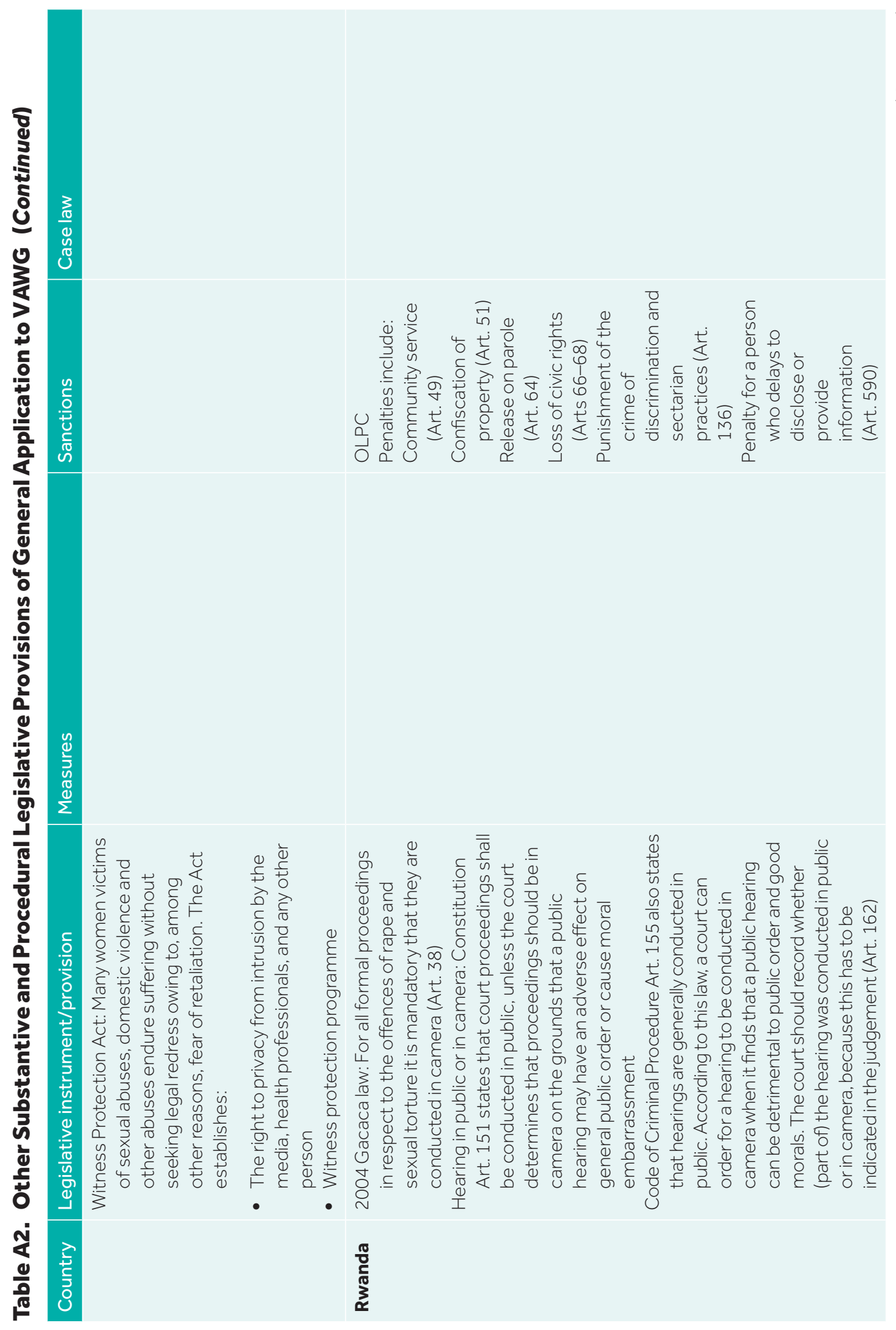




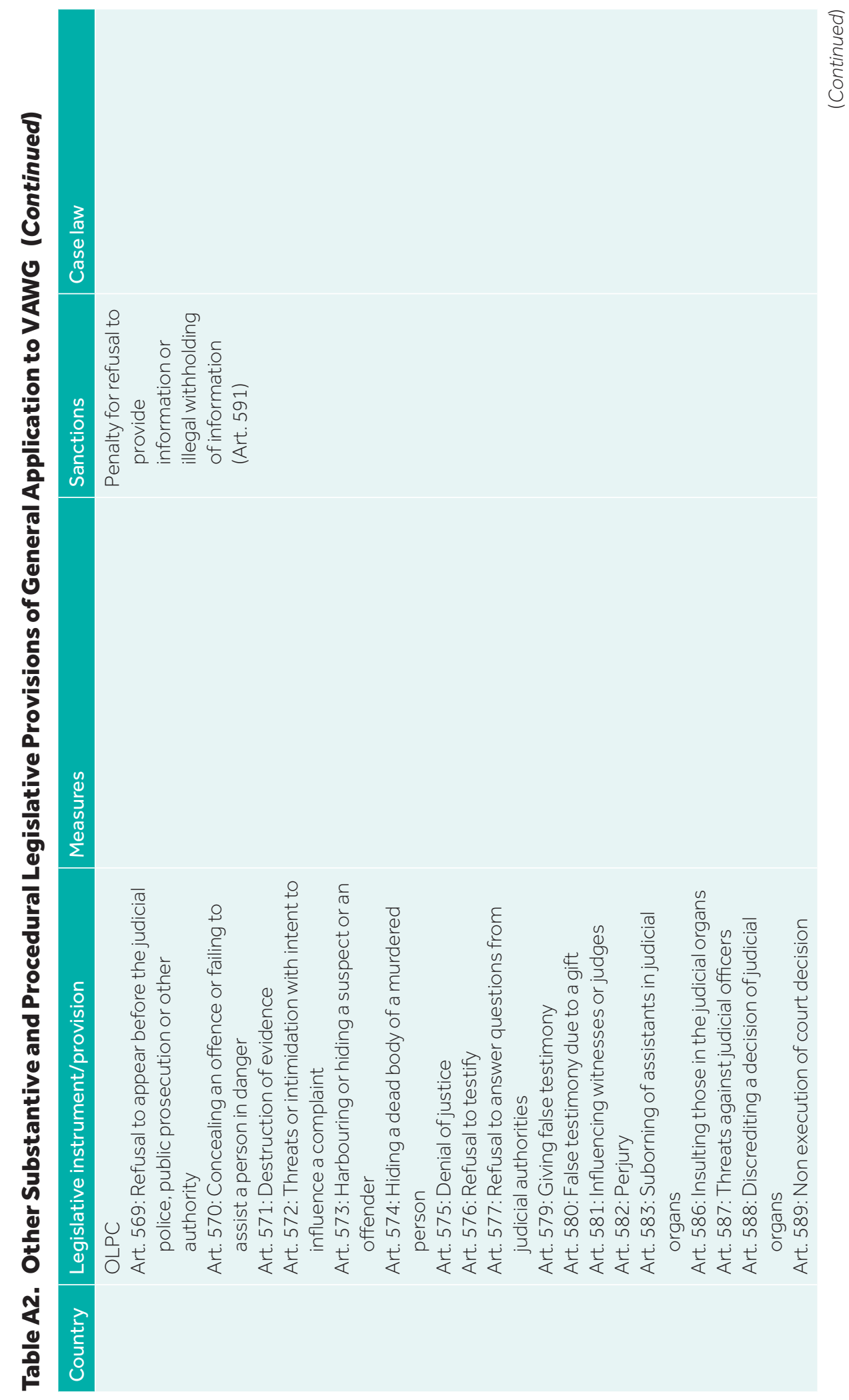




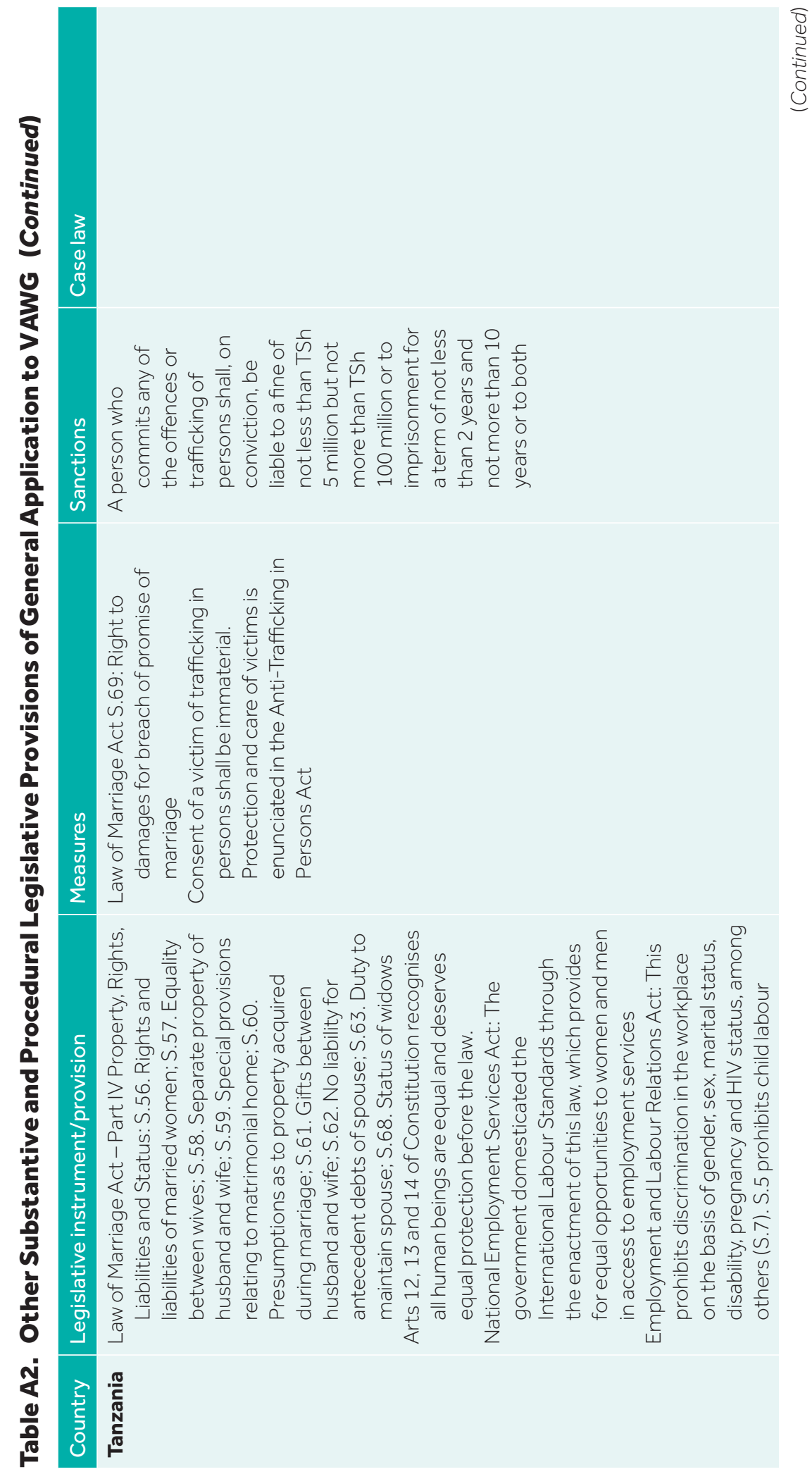




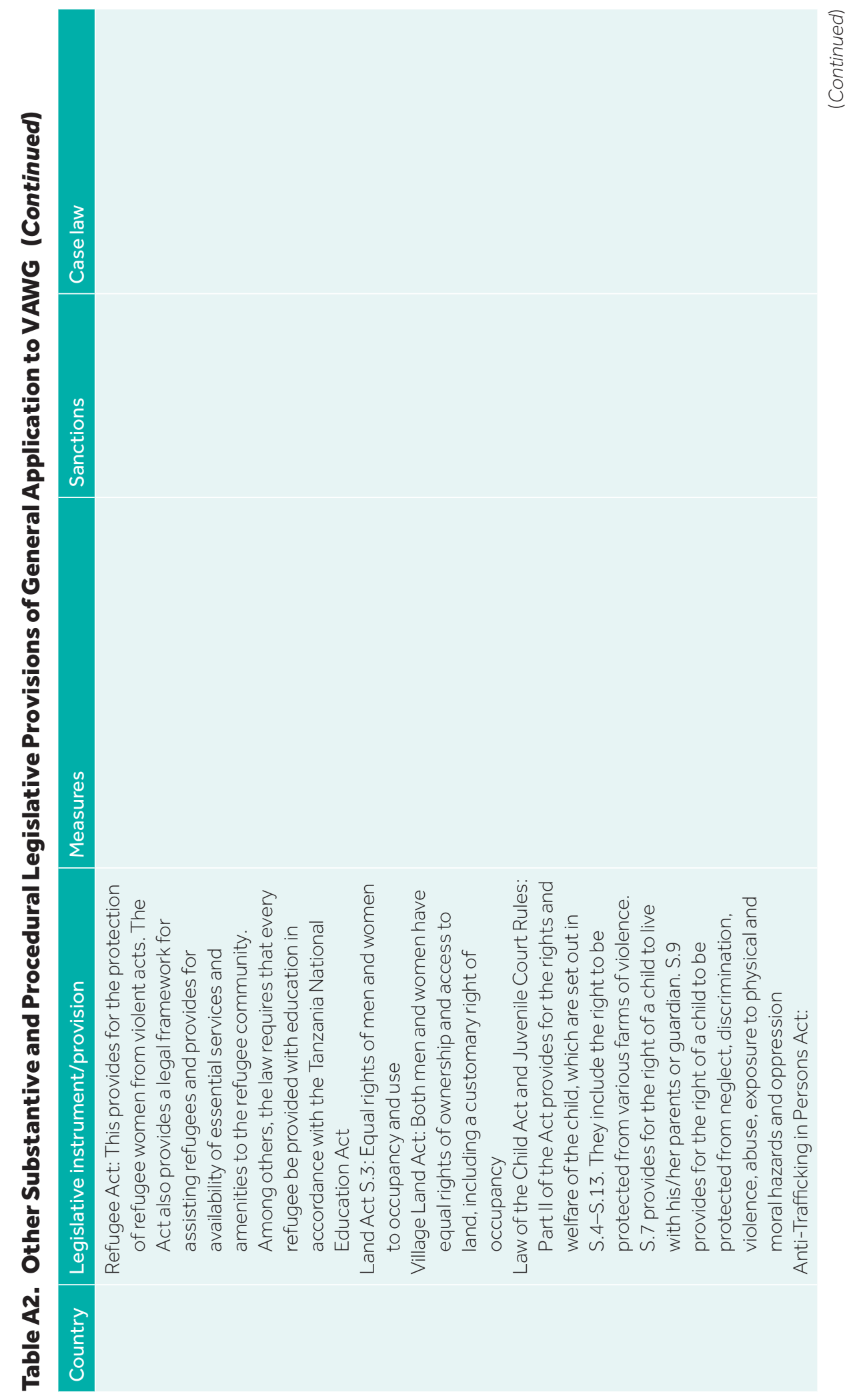




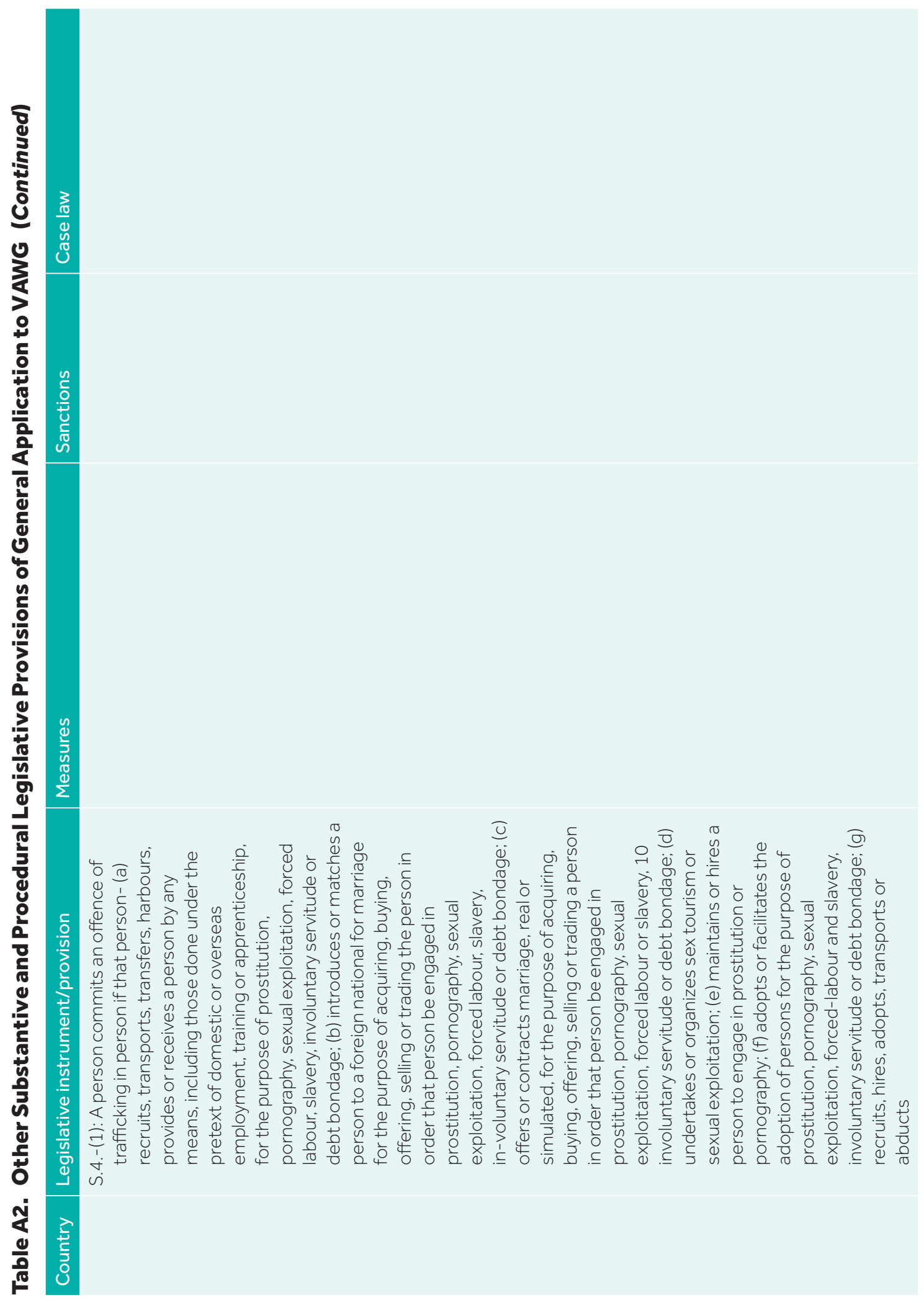




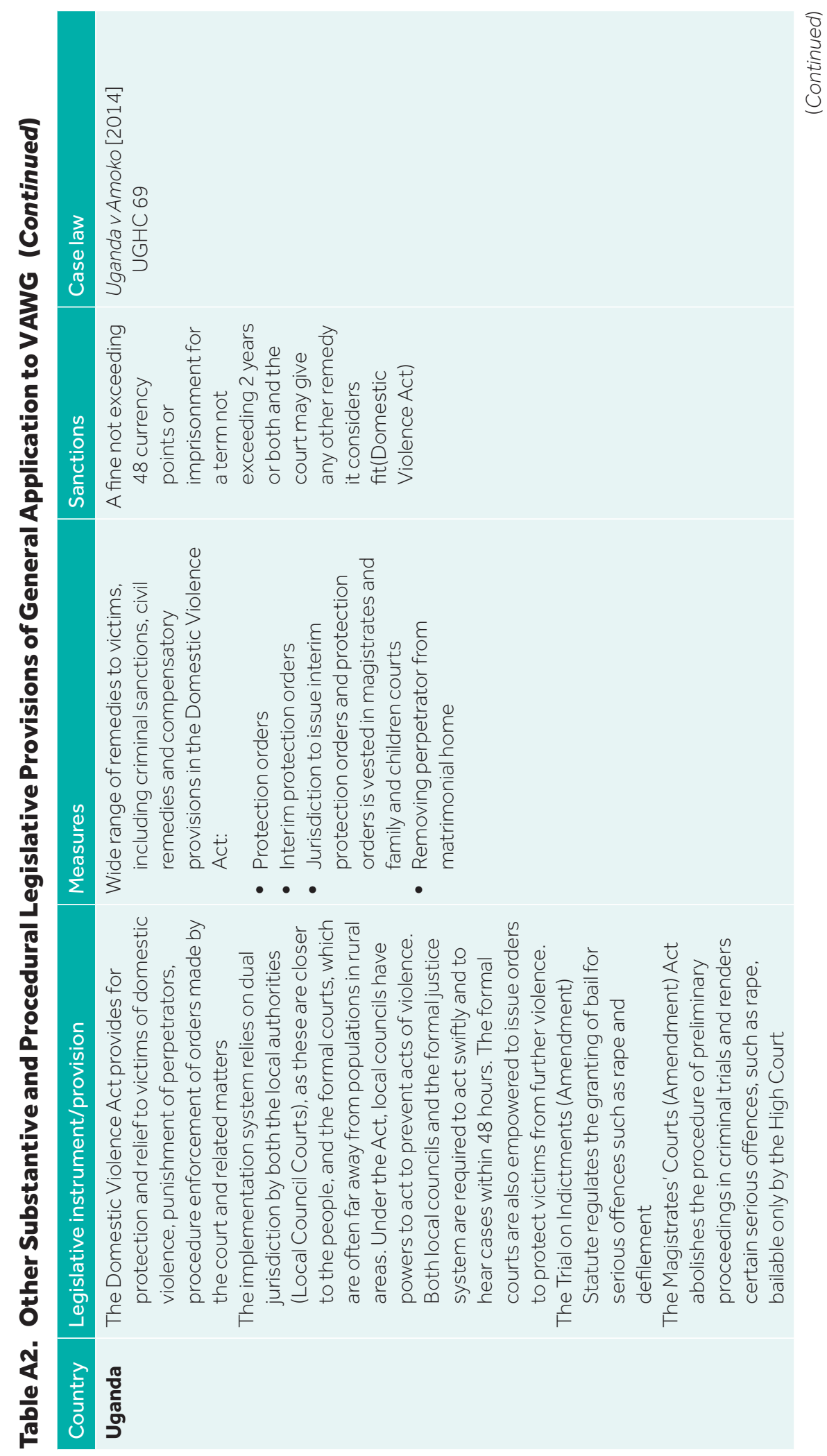




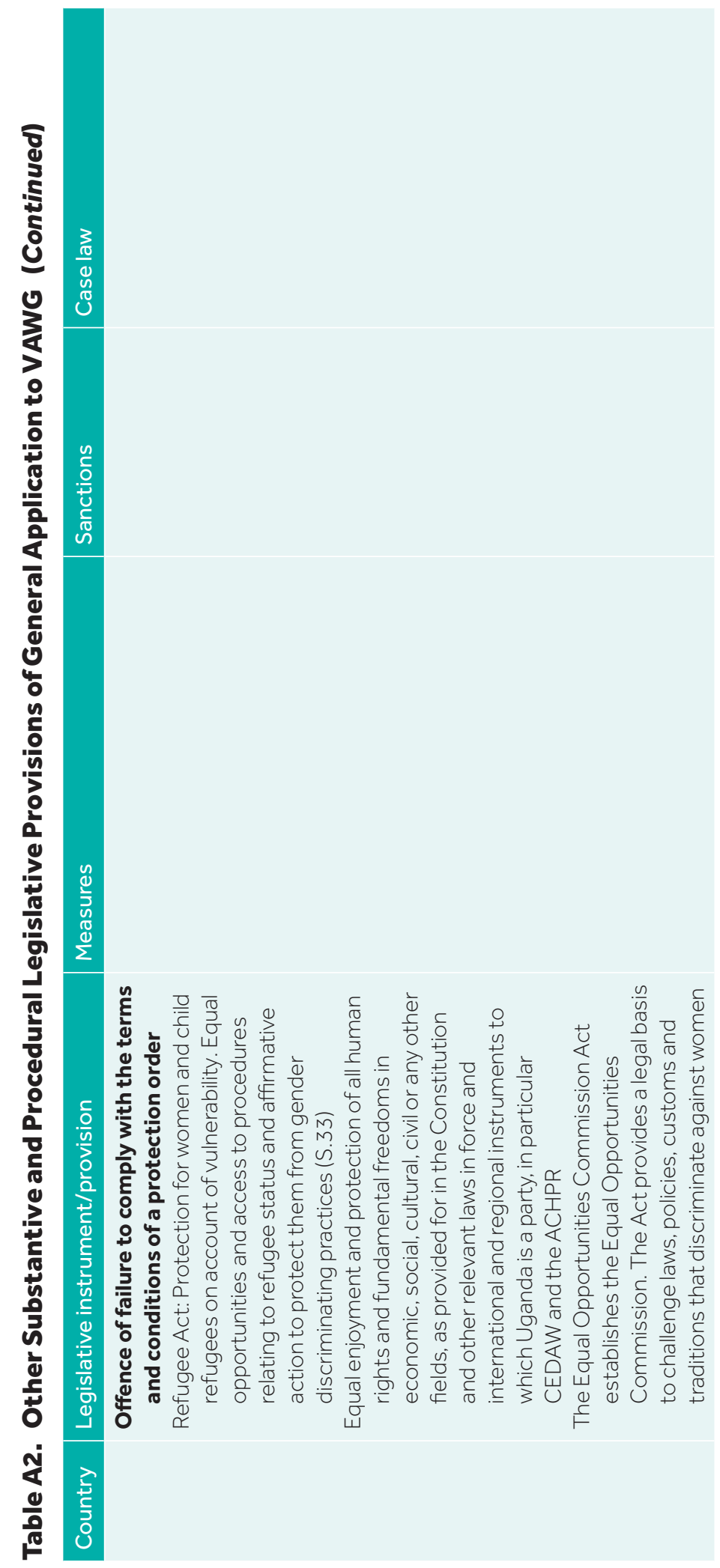




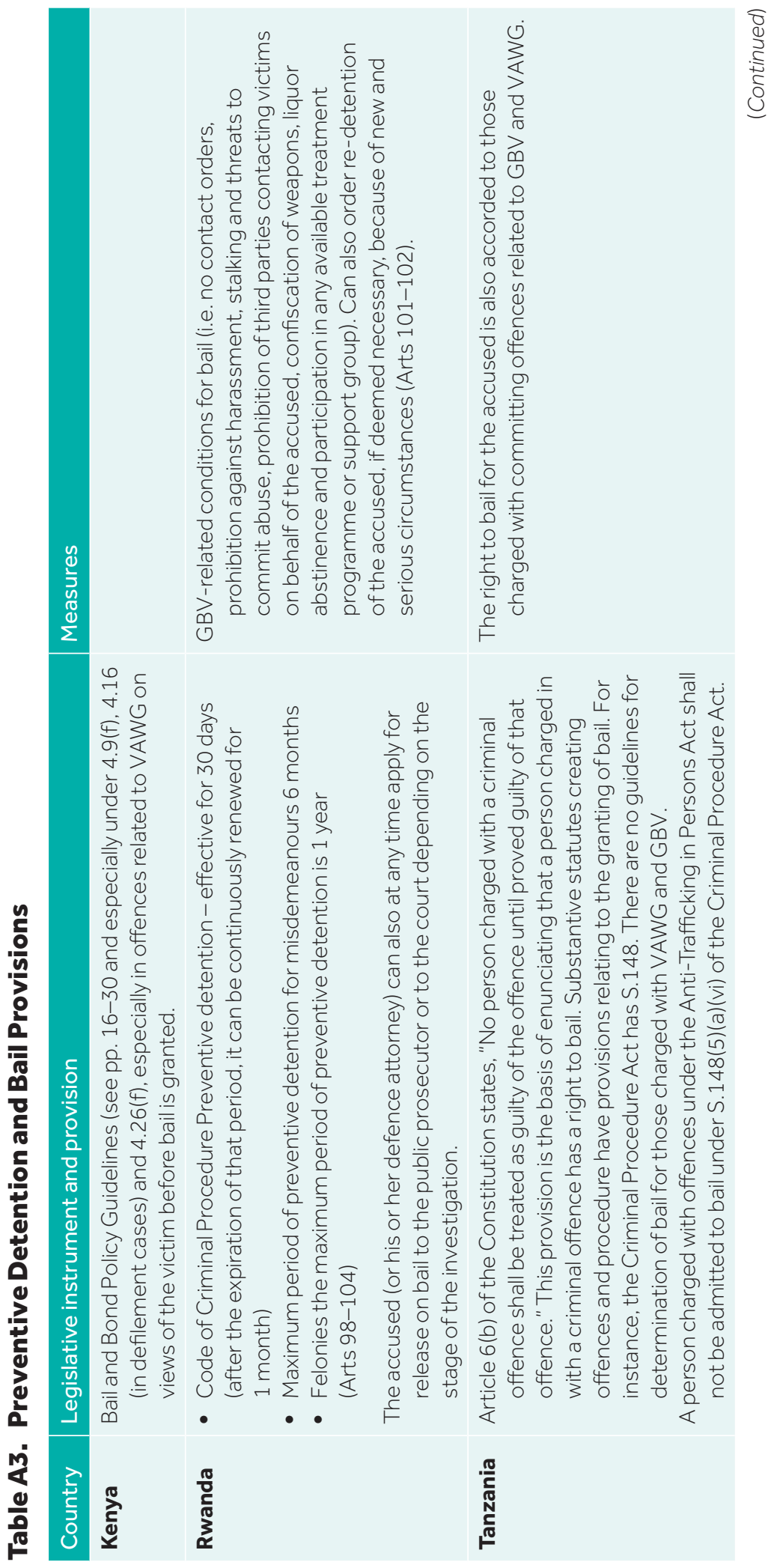




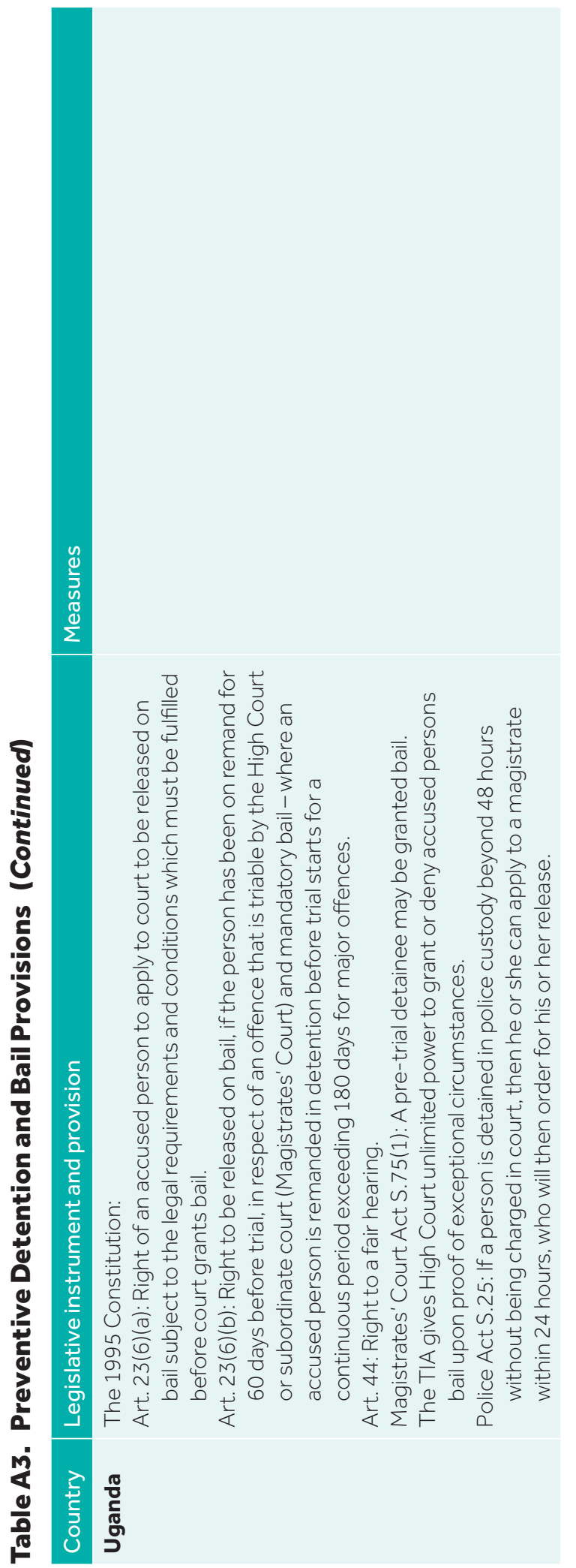

